\title{
Alum sludge as an efficient sorbent for hydrogen sulfide removal: Experimental, mechanisms and modeling studies
}

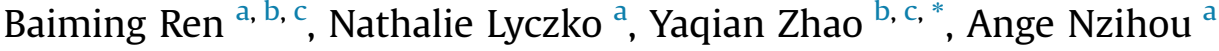 \\ a Université de Toulouse, IMT Mines Albi, RAPSODEE CNRS UMR-5302, Campus Jarlard, Albi, 81013, Cedex 09, France \\ ${ }^{\mathrm{b}}$ Centre for Water Resources Research, School of Civil Engineering, University College Dublin, Belfield, Dublin 4, Ireland \\ ' State Key Laboratory of Eco-Hydraulics in Northwest Arid Region, Xi'an University of Technology, Xi'an, 710048, PR China
}

\section{H I G H L I G H T S}

- First study of reusing alum sludge for $\mathrm{H}_{2} \mathrm{~S}$ adsorption.

- The effect of flow rate and bed depth were investigated.

- The adsorption mechanisms were proposed.

- Three kinetic adsorption models were applied for breakthrough behavior simulation.

- Mass transfer coefficients of the sorbent were determined.

\section{G R A P H I C A L A B S T R A C T}

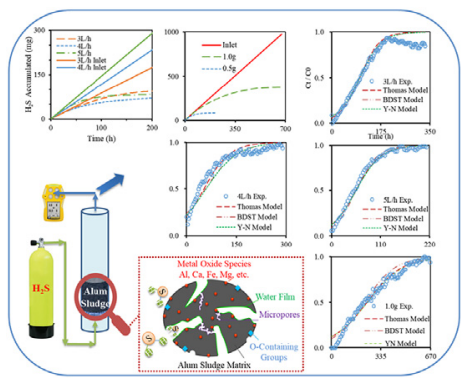

A B S T R A C T

This paper firstly reported a systematic study of using alum sludge (waterworks residue) for $\mathrm{H}_{2} \mathrm{~S}$ adsorption. Various trials were performed at ambient temperature in a fixed bed column to study the effects of $\mathrm{H}_{2} \mathrm{~S}$ flow rate, sorbent bed depth on the alum sludge adsorption efficiency of $\mathrm{H}_{2} \mathrm{~S}$. The Breakthrough Curves were simulated by the Thomas model, Bed Depth Service Time model and YoonNelson models. The mechanisms of $\mathrm{H}_{2} \mathrm{~S}$ adsorption onto alum sludge was examined by different physiochemical characterizations of exhausted and raw alum sludge. Moreover, the mass transfer coefficients were determined from mathematical descriptions of breakthrough curves. The alum sludge adsorption capacity was determined to be $374.2 \mathrm{mg}$ of $\mathrm{H}_{2} \mathrm{~S} / \mathrm{g}$, slightly decreasing with the increasing flow rate and increasing with the increasing bed depth. All the three models successfully predict breakthrough curves which could be used for scaling-up purposes. The microporous structure, alkaline $\mathrm{pH}$ and the inherent metal species of the alum sludge promoted the formation of metal sulphate species. This study demonstrated that alum sludge could be used as cost-effective, largely available, and efficient sorbent for $\mathrm{H}_{2} \mathrm{~S}$ removal.
Adsorption

Alum sludge

Breakthrough curves

Desulfurization

Fixed-bed reactor

Mass transfer coefficient

\section{Introduction}

There is generally increasing public concern for and intolerance of odors and other air contaminants from sewerage facilities.

\footnotetext{
* Corresponding author. Xi'an University of Technology, Xi'an, 710048, PR China E-mail address: yaqian.zhao@ucd.ie (Y. Zhao).
}

Management of air/odor emissions has become a significant activity in wastewater treatment plants (WWTPs). Furthermore, national and local regulations require a number of air pollutants to be controlled (de Oliveira, 2011). Hydrogen sulfide $\left(\mathrm{H}_{2} \mathrm{~S}\right)$ is one of several odorous gases from industrial effluents such as WWTPs, landfill sites and petrochemical industries (Bamdad et al., 2018). It is a poisonous, flammable, colorless gas with a characteristic odor of rotten eggs. The average odor threshold of $\mathrm{H}_{2} \mathrm{~S}$ is reported at 7 to 
9 part per billion (ppb) (Wu et al., 2018).

Generally, treatment technologies of $\mathrm{H}_{2} \mathrm{~S}$ in WWTPs include physical/chemical (such as adsorption, chemical scrubbing) and biological methods (biofiltration, biotrickling, activated sludge diffusion etc.) (Ren et al., 2019). Adsorption, a process based on the transfer of pollutants from gas phase to solid phase, has been broadly implemented. It is one of the most suitable methods for $\mathrm{H}_{2} \mathrm{~S}$ removal from a gas stream, as it allows for $\mathrm{H}_{2} \mathrm{~S}$ removal to less than 1 ppmv (Patel, 2019). For instance, in recent studies, Singh et al. (2019) used zinc oxide-decorated multi-wall carbon nanotubes (ZnO-MWCNTs), which was a synthesis of the carbon nanotube and zinc oxide, for a high values (98\%) of $\mathrm{H}_{2} \mathrm{~S}$ removal in a bench-scale fixed bed reactor at the ambient temperature and atmospheric. Sánchez-González et al. (2018) investigated Mg-based metal-organic frameworks (MOFs) as a highly reversible sorbent for $\mathrm{H}_{2} \mathrm{~S}$ removal. The dynamic adsorption experiments were performed at $303 \mathrm{~K}$ using a quartz-tube filled with Mg-MOF. Results showed that the $\mathrm{H}_{2} \mathrm{~S}$ adsorption capacity of Mg-MOF was $3.1 \mathrm{mmol}$ $\mathrm{H}_{2} \mathrm{~S} / \mathrm{g}$, under the $15 \mathrm{vol} \% \mathrm{H}_{2} \mathrm{~S}$ feed concentration. Hervy et al. (2018) reported the $\mathrm{H}_{2} \mathrm{~S}$ removal by chars obtained from pyrolysis of wastes under ambient temperature in various dry gas matrices $\left(\mathrm{N}_{2}\right.$, Air, Syngas). It concluded that the most efficient material was the steam activated char from food waste and coagulation-flocculation sludge, with a removal capacity of $65 \mathrm{mg} \mathrm{H}_{2} \mathrm{~S} / \mathrm{g}$ under dry syngas.

Other materials have been reported as sorbents for $\mathrm{H}_{2} \mathrm{~S}$ removal, including fly ash, activated carbon, polymers, carbon-coated polymers, ceramics, and synthetic zeolites. The $\mathrm{H}_{2} \mathrm{~S}$ removal efficiency of these materials ranged from 8.63 to $210 \mathrm{mg} \mathrm{H}_{2} \mathrm{~S} / \mathrm{g}$ (Sharma and Verma, 2013; Sitthikhankaew et al., 2014; Wang et al., 2017). Activated carbon was applied in most of the studies dealing with $\mathrm{H}_{2} \mathrm{~S}$ removal (based on moist air) at room temperature. During the sorption process, $\mathrm{H}_{2} \mathrm{~S}$ could have interactions with $\mathrm{O}$-containing groups and/or mineral species in the sorbent (in the presence of oxygen and humidity). This also results in several retention mechanisms including adsorption, dissociation and oxidation (Hervy et al., 2018; Chanaka Udayanga et al., 2019a). However, the removal capacity of $\mathrm{H}_{2} \mathrm{~S}$ by adsorptive materials depends on physicochemical properties (e.g., elemental composition, pore structure, surface O-containing groups, mineral species and $\mathrm{pH}$ ) of the materials and varies with experimental conditions (e.g., temperature, water and/or oxygen) (Bamdad et al., 2018, Chanaka Udayanga et al., 2018; 2019b). Indeed, adsorption has the common shortcoming including material cost and the complexity of sorbent preparation. Therefore, direct utilization of low-cost raw materials from industrial by-product for $\mathrm{H}_{2} \mathrm{~S}$ removal has attracted intensive research interests.

Alum sludge (or Al-waterworks residue) is a kind of by-product during drinking water treatment process in waterworks where aluminum based coagulant is applied (Zhao et al., 2018a). It is a locally, easily and largely available "resources" in towns, cities and metropolis and free of charge for the moment. Unfortunately, it is treated as a "waste" for landfilling in most of the places in the world. Therefore, identifying novel, sustainable alum sludge reuse methods may provide significant social and environmental benefits. Actually, alum sludge has been intensively studied in recent years as a low-cost sorbent for phosphorous and other pollutants (Shen et al., 2019; Liu et al., 2018; Wang et al., 2018; Zhao et al., 2018b) and has been advocated to be a valuable reuse product, offering huge potential for a number of pollutants immobilization with unique feature of using "waste" for waste treatment (Yang et al., 2018; Zhao et al., 2016). However, to the best of our knowledge, no studies have used alum sludge for $\mathrm{H}_{2} \mathrm{~S}$ adsorption even it has been intensively studied and demonstrated to be a good material for impurities adsorption in wastewater treatment, i.e. pollutants in aquatic phase (Ahmad et al., 2016; Hidalgo et al., 2017;
Odimegwu et al., 2018).

Fixed-bed column is commonly employed for adsorption studies as it can be relatively easy to scaling up, but a fixed-bed column does not always run under equilibrium conditions, the performance depends on the flow conditions and mass-transfer phenomena (Gutiérrez Ortiz et al. 2014; Long and Loc, 2016). The breakthrough curve (e.g., the dynamic behavior of adsorption process) describes the effluent concentration with time profile, which is vital in the evaluation of the material efficacy. The shape of the breakthrough curve is also affected by both inter- and intra-particle transfer phenomenon in the column and sorbent (Kubonova et al., 2011). Therefore, breakthrough curves measuring and mass transfer phenomena are fundamental for understandings and predicting sorption phenomenon. Mathematical models are useful for describing and predicting the behavior of fixed-bed reactors and help to optimize as well as to design a system. The most commonly used models in literature are Thomas, Bed Depth Service Time, and Yoon-Nelson models, which are all used in this study.

Accordingly, this paper firstly systematically reported the experimental adsorption behavior modeling and mechanisms of using alum sludge for $\mathrm{H}_{2} \mathrm{~S}$ adsorption in a fixed-bed column at room temperature. The effects of reaction/adsorption conditions were trialed while three modeling approaches (Thomas, Bed Depth Services Time, Yoon-Nelson model) were examined and compared. Moreover, the adsorption mechanisms were proposed and the mass transfer coefficient was determined, which could be used to design and evaluate the alum sludge reactor on a larger scale. This study intends to pave a novel reusing route of alum sludge as $\mathrm{H}_{2} \mathrm{~S}$ abatement media.

\section{Materials and methods}

\subsection{Sorbent and characterization}

Dewatered raw alum sludge cakes were obtained from the Carmaux drinking water treatment plant located in Tarn, France. The plant produces $3014 \mathrm{~m}^{3} /$ day of drinking water by treating raw water using aluminum sulphate as a coagulant. After collection, the sludge was dried, mechanically ground by a blender and sieved to pass a $250 \mu \mathrm{m}$ mesh. Alum sludge moisture content was determined by drying at $105^{\circ} \mathrm{C}$ for $24 \mathrm{~h}$ and measuring the mass difference before and after drying.

Different physicochemical characteristics were determined before and after $\mathrm{H}_{2} \mathrm{~S}$ sorption. The alum sludge $\mathrm{pH}$ was measured by adding $0.5 \mathrm{~g}$ of alum sludge to $20 \mathrm{ml}$ of distilled water. Particle size distribution was determined by a laser particle sizer MALVERN Laser Mastersizer Hydro 2000 at size interval of $0.01-1000 \mu \mathrm{m}$. Inductively coupled plasma atomic emission spectroscopy (ICPAES) was performed by using HORIBA Jobin-Yvon Ultima 2. Scanning electron microscopy (SEM) was employed (Philips XL30 ESEM apparatus, FEI Company), it was coupled with an energy-dispersive X-ray spectroscopy (EDX analysis). The transmission electron microscopy (TEM) was used on the JEOL JEM-ARM200F and the elemental mapping of chemical species in the sample was performed by using an EDX module in the same microscope. Specific surface area and pore structure were determined by the BET method (Micromeritics Gemini Vacprep 061). The pore structure of alum sludge was determined by nitrogen adsorption at $77 \mathrm{~K}$ using a Micromeritics 3 Flex high-resolution analyzer.

To investigate the various resultant sulfur products, a thermogravimetric analysis (ATG STA409PC, Netzsch) coupled with a mass spectrometer (OMNISTAR, Pfeiffer) was applied. Heating rate of $20^{\circ} \mathrm{C} / \mathrm{min}$ up to $800^{\circ} \mathrm{C}$ at a nitrogen flow rate of $3 \mathrm{~L} / \mathrm{h}$ was used. For each measurement, a sample of $200-300 \mathrm{mg}$ of alum sludge was analyzed. 


\subsection{Sorption trials}

The $\mathrm{H}_{2} \mathrm{~S}$ removal trials were carried out at ambient temperature $\left(20^{\circ} \mathrm{C}\right)$ by using a glass fixed-bed column. Fixed bed columns test can be easily scaled up from a laboratory to an industrial application (de Franco et al., 2018). Fig. 1 shows the photographic description of the column setup. The column (length $60 \mathrm{~mm}$, internal diameter $11 \mathrm{~mm}$ ) is equipped with a porous glass disc at the bottom which could hold alum sludge and allow $\mathrm{H}_{2} \mathrm{~S}$ to pass through. The height of alum sludge layer varied from about 5 to $11 \mathrm{~mm}$, corresponding to the amount of alum sludge used for each trial (0.5-1.0 g). A synthetic gas containing 200 ppmv of $\mathrm{H}_{2} \mathrm{~S}$ (based on dry air) passed through alum sludge at different flow rates of 3 , $4,5 \mathrm{~L} / \mathrm{h}$, respectively, as controlled by a flow meter. The outlet $\mathrm{H}_{2} \mathrm{~S}$ concentration was monitored every 2 min using a gas analyzer (BW Technologies, Gas Alert QUATTRO). The effluent gas was treated by a $\mathrm{CaO}$ solution before it was released to the atmosphere. Sorption experiments were ended when the $\mathrm{H}_{2} \mathrm{~S}$ sorption rate significantly decreased. During the various trials, material fluidization was not observed under three flow rates $(3,4$ and $5 \mathrm{~L} / \mathrm{h})$ and the space velocity of 3,4 and $5 \mathrm{~L} / \mathrm{h}$ are $526 \mathrm{~h}^{-1}, 702 \mathrm{~h}^{-1}$ and $877 \mathrm{~h}^{-1}$, respectively. In this study, the following Eqs. (1) and (2) are used in order to calculate the accumulation of $\mathrm{H}_{2} \mathrm{~S}: 1$ ) $\mathrm{H}_{2} \mathrm{~S}_{\text {input }}(\mathrm{mg}$ ) represents the total quantity of $\mathrm{H}_{2} \mathrm{~S}$ put into the bed at a given time; 2) Accumulated sorbent $(\mathrm{mg})$ refers to the $\mathrm{H}_{2} \mathrm{~S}$ accumulated quantity on alum sludge at a given time.

$H_{2} S_{\text {input }}=\frac{P Q M}{10^{6} R T} C_{0} t$

Accumulated $_{\text {sorbent }}=\frac{P Q M}{10^{6} R T}\left[C_{0} t \int_{0}^{t} C_{t} d t\right]$

where, $P$ represents the pressure of gas ( $1 \mathrm{~atm}), Q$ is the inlet flow rate $\left(\mathrm{L} \mathrm{min}^{-1}\right), M$ is the molecular weight of $\mathrm{H}_{2} \mathrm{~S}\left(34.06 \mathrm{~g} \mathrm{~mol}^{-1}\right), C_{0}$ is the inlet concentration of $\mathrm{H}_{2} \mathrm{~S}(200 \mathrm{ppmv})$, while $C_{t}$ is the outlet concentration of $\mathrm{H}_{2} \mathrm{~S}$ (ppmv), $t$ is the reaction time (min), $R$ is the standard ideal gas constant $(8.31 \mathrm{~J} / \mathrm{mol} \cdot \mathrm{K})$, and $T$ is the temperature (K).

\subsection{Modeling}

The three most commonly used models to describe the experiment data in breakthrough curves are the Thomas, Bed Depth Service Time, and Yoon-Nelson models, all used in this study (de Franco et al., 2018; Long and Loc, 2016; Rout et al., 2017).

The Thomas model (Thomas, 1944) is applied to evaluate sorbent adsorption capacity in a fixed bed column, and is useful in practical applications. It is based on two hypotheses: (i) the adsorption follows Langmuir isotherms and second-order sorption-desorption kinetics with no axial dispersion; and (ii) the adsorption is controlled by the mass transfer at the interface. The linearized form of the model is given as:

$\ln \left(\frac{C_{0}}{C_{t}}-1\right)=\frac{K_{T h} q_{0} m}{F}-K_{T h} C_{0} t$

where, $\mathrm{K}_{\mathrm{Th}}$ refers to Thomas rate constant $\left(\mathrm{L} \mathrm{mg}^{-1} \mathrm{~min}^{-1}\right)$, $\mathrm{q}_{0}$ represents adsorption capacity $\left(\mathrm{mg} \mathrm{g}^{-1}\right), \mathrm{m}$ is the mass of sorbent in the column $(\mathrm{g})$, while $\mathrm{F}$ is the volumetric flow rate $\left(\mathrm{L} \mathrm{min}^{-1}\right)$. The kinetic coefficient $\mathrm{K}_{\mathrm{Th}}$ and the adsorption capacity of the sorbent $\mathrm{q}_{0}$ can be determined from a plot of $\ln \left[\left(C_{0} / C_{t}\right)-1\right]$ against $t$ at a given flow rate.

The BDST model (Hutchins, 1973) was used to describe the relationship between the service time and the column packed-bed depth. It mainly focuses on predicting the time taken by the sorbent to remove a specific amount of adsorbate from bulk phase before exhaustion. This model is based on the assumption that the surface reaction step is rate-controlling. The model is given as:

$\mathrm{t}=\frac{N_{0} h}{u C_{0}}-\frac{1}{K C_{0}} \ln \left(\frac{C_{0}}{C_{t}}-1\right)$

where, $\mathrm{K}$ is the constant $\left(\mathrm{L} \mathrm{mg}^{-1} \mathrm{~min}^{-1}\right), \mathrm{N}_{0}$ is the adsorption capacity $\left(\mathrm{mg} \mathrm{L}^{-1}\right), \mathrm{h}$ is the bed depth $(\mathrm{cm}), \mathrm{u}$ refers to the linear flow rate $\left(\mathrm{cm} \mathrm{min}{ }^{-1}\right)$, and $t$ is breakthrough times (min). BDST curves can be plotted using adsorption data, while estimation of the characteristic parameters $\mathrm{K}$ and $\mathrm{N}_{0}$ can be computed from the slope and intercept of the plots.

To evaluate a fixed bed adsorption kinetics, the Yoon-Nelson model (Yoon and Nelson, 1984) is often used, which is based on the assumption that the rate of decrease in the probability of adsorption for each adsorbate molecule is proportional to the
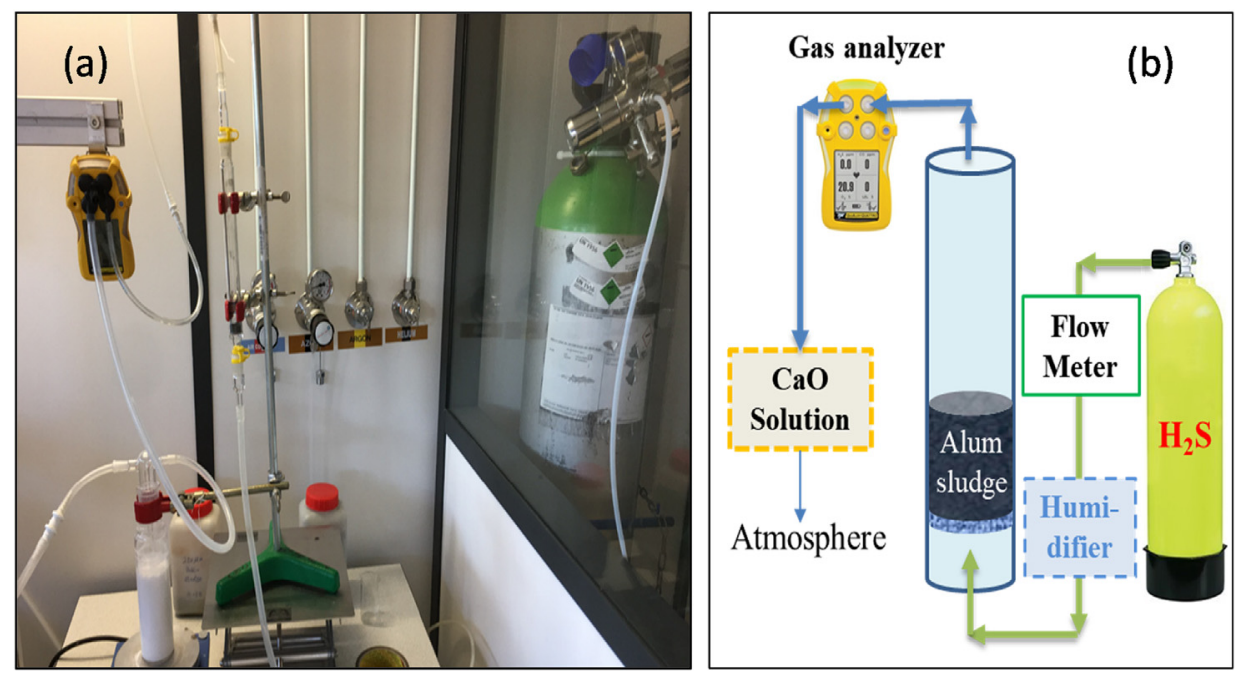

Fig. 1. Photographic description (a), and the schematic description (b) of the fixed-bed adsorption system. 
probability of adsorbate adsorption and the probability of adsorbate breakthrough on the sorbent. The model provides information about the breakthrough rate in a fixed-bed column and the time realized to achieve $50 \%$ breakthrough. The linearized model for a single component system is expressed as:

$\ln \frac{C_{t}}{C_{0}-C_{t}}=K_{Y N} t-\tau K_{Y N}$

where, $\mathrm{K}_{\mathrm{YN}}$ is the rate constant $\left(\mathrm{min}^{-1}\right)$ and $\tau$ is the special time required for $50 \%$ adsorbate breakthrough ( $\mathrm{min}$ ). The calculation of theoretical breakthrough curves for a single-component system requires the determination of the parameters $K_{Y N}$ and $\tau$ for the adsorbate from the plot of $\ln \left[\mathrm{C}_{\mathrm{t}} /\left(\mathrm{C}_{0}-\mathrm{C}_{\mathrm{t}}\right)\right]$ versus sampling time $(\mathrm{t})$.

\subsection{Determination of mass transfer coefficient}

Mass transfer was described as a lumped overall resistance. Ideal homogeneous phase was the original thought of sorbent particle, diffusion occurs with a constant effective diffusivity, mass transport is slower than reaction kinetics (Gutiérrez Ortiz et al. 2014). Thus, the mass transfer is described as:

$\frac{\partial q}{\partial t}=K_{a}\left(q_{e}-q\right)$

where, $K_{\mathrm{a}}$ represents overall effective mass transfer coefficient, $\mathrm{q}_{\mathrm{e}}$ is the value of $q$ in equilibrium with $\mathrm{C}$, q is the concentration of $\mathrm{H}_{2} \mathrm{~S}$ (or load) in solid phase.

If the equilibrium isotherm is linear $\left(\mathrm{q}_{\mathrm{e}}=\mathrm{K}_{\mathrm{e}} \mathrm{C}\right)$, an analytic expression can be derived, such as Klinkenberg performed (Klinkenberg, 1948) using dimensionless equations as follows:

Mass balance in the bed:

$\frac{\partial \varphi}{\partial \xi}+\frac{\partial \phi}{\partial \tau}=0$

Adsorption velocity:

$\frac{\partial \phi}{\partial \tau}=\varphi-\phi$

where: $\varphi=\frac{c}{C_{0}} ; \phi=\frac{q}{q_{s}} ; \xi=\frac{K_{e} K_{a} Z}{u}\left(\frac{1-\varepsilon}{\varepsilon}\right) \quad \tau=K_{a}\left(t-\frac{z}{u}\right) \mathrm{q}_{\mathrm{s}}$ is the exhausted value of $\mathrm{q}, \mathrm{K}_{\mathrm{e}}$ is the equilibrium constant, $\mathrm{z}$ is the distance from the bed entrance, $u$ is the gas interstitial velocity, $\varepsilon$ is the bed void fraction, and $\mathrm{t}$ is the time. Therefore, by considering the initial and boundary conditions, the analytical solution is as follows:

$\left.\left.\frac{C}{C_{0}} \approx \frac{1}{2} 1+\operatorname{erf} \sqrt{\tau}-\sqrt{\xi}+\frac{1}{8 \sqrt{\tau}}+\frac{1}{8 \sqrt{\xi}}\right)\right)$

where, $\operatorname{erf}(\mathrm{x})$ is the Gauss error function, defined by Eq. (10).

$\operatorname{erf}(x)=\frac{2}{\sqrt{ } \pi} \int_{0}^{x} e^{-t^{2}} d t$

The overall mass transfer coefficient (e.g., external and internal mass transfer) was given as:

$\frac{1}{K_{e} K_{a}}=\frac{d_{p}}{6 K_{e x t}}+\frac{d_{p}^{2}}{60 D_{e}}$

$d_{p}$ is the mean particle diameter, $D_{e}$ is the effective diffusivity.

The external mass transfer coefficient $\left(K_{\text {ext }}\right)$ was determined by the Ranz-Marshall correlation (Ranz and Marshall, 1952):

$S h=2+1.58 R e^{0.4} S c^{1 / 3} ; 10^{-3} \leq \operatorname{Re} \leq 5.8$

where: $S h=\frac{K_{\text {ext }} d_{p}}{D_{m}} ; \operatorname{Re}=\frac{u \varepsilon d_{p} \rho}{\mu} ;=S c \frac{\mu}{\rho D_{m}} \mathrm{D}_{\mathrm{m}}$ is the molecular diffusivity, $d_{p}$ is particle diameter, $q$ is gas density, $\mu$ is gas viscosity. The Fuller-Schettler-Gridding correlation was used to calculated $D_{m}$ (Fuller et al., 1966):

$D_{m}=\frac{10^{-3} T^{1.75}}{P} \frac{\left(\frac{1}{M_{\text {gas }}}+\frac{1}{M_{\mathrm{H}_{2} S}}\right)^{0.5}}{\left(V_{\text {gas }}^{1 / 3}+V_{\mathrm{H}_{2} S}^{1 / 3}\right)^{2}}$

where, $\mathrm{T}$ in $\mathrm{K}, \mathrm{M}$ is molecular weight, $\mathrm{V}$ is the diffusion volume, $\mathrm{D}_{\mathrm{m}}$ in $\mathrm{cm}^{2} / \mathrm{s}$. $\mathrm{D}_{\mathrm{e}}$ is effective diffusivity, which could be calculated by the Bosanquet equation (Gutiérrez Ortiz et al. 2014):

$D_{e}=\frac{\varepsilon_{p}}{f_{\text {tor }}}\left[\frac{1}{D_{m}}+\frac{1}{D_{K}}\right]^{-1}$

where, $\varepsilon_{\mathrm{p}}$ is particle porosity, $\mathrm{f}_{\mathrm{tor}}$ is tortuosity factor, $\mathrm{D}_{\mathrm{K}}$ is the Knudsen diffusivity, which is given by Eq (15).

$D_{k}=4850 d_{\text {pore }}\left(\frac{T}{M_{\mathrm{H}_{2} \mathrm{~S}}}\right)^{1 / 2}$

where, $d_{\text {pore }}$ is the mean pore diameter.

\section{Results and discussion}

\subsection{Sorbent characterization}

The moisture content of alum sludge cake was $63 \mathrm{wt} \%$, while the mean particle diameter $\left(\mathrm{d}_{50}\right)$ of the alum sludge was $16.5 \mu \mathrm{m}$. Aluminum and calcium were the most abundant elements. Other elements were also present, including various metals, silicon and phosphorus. The $\mathrm{pH}$ of the alum sludge is 10 , indicating the basicity. The total carbon is $30.6 \mathrm{wt} \%$ which is composed of $3.6 \mathrm{wt} \%$ inorganic carbon and $27.0 \mathrm{wt} \%$ organic carbon (in Table S1). Important to note, alum sludge shows a high specific surface area of $257.1 \mathrm{~m}^{2} /$ g, greater than "normal" sorbents such as used wood pellets chars $\left(78.8 \mathrm{~m}^{2} / \mathrm{g}\right.$ ) (Hervy et al., 2018); municipal solid waste incineration (MSWI) fly ash $\left(17.7 \mathrm{~m}^{2} / \mathrm{g}\right.$ ) (Wu et al., 2018); and rice husk activated carbon $\left(168 \mathrm{~m}^{2} / \mathrm{g}\right.$ ) (Nam et al., 2018). The relatively high specific surface area was due to the addition of activated carbon before the raw water purification processes in Carmaux (France) waterworks, in order to remove the odor and tastes of raw water.

The microstructures of the alum sludge were obtained by SEM and a representative EDS analysis which showed the chemical composition of its surface. Analysis result by EDX indicated a relatively large amount of $C$ on the alum sludge. From the physical texture, the alum sludge presents a porous and rigid structure with many irregular particles being observed (Fig. S1). In particular, as shown in the EDX analysis, there are various metal elements on the surface of alum sludge, such as $\mathrm{Al}, \mathrm{Fe}, \mathrm{Mg}, \mathrm{Ca}$, and it have been demonstrated that adsorption of $\mathrm{H}_{2} \mathrm{~S}$ largely depends on the metal species contained in the materials and reacted with $\mathrm{H}_{2} \mathrm{~S}$ to produce metal sulfides (Hervy et al., 2018).

\subsection{Sorption trials}

Fig. 2 shows the sorption results obtained with $0.5 \mathrm{~g}$ alum sludge under different flow rate of $3,4,5 \mathrm{~L} / \mathrm{h}$, respectively. The inlet curve describes the quantity of introduced $\mathrm{H}_{2} \mathrm{~S}$ into the bed. Other 


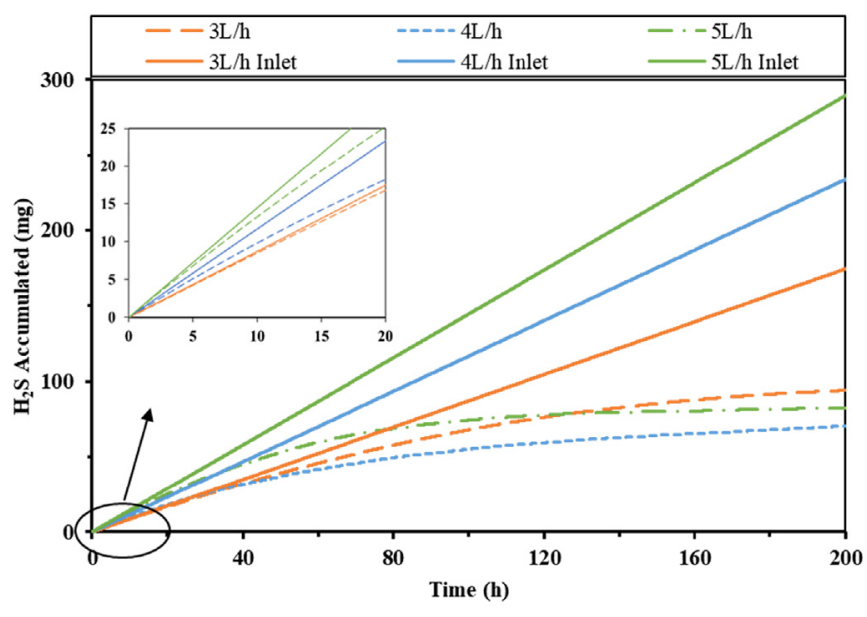

Fig. 2. Quantity of the $\mathrm{H}_{2} \mathrm{~S}$ fed into the reactor (Inlet curve) and fixed on $0.5 \mathrm{~g}$ alum sludge under different flow rate.

curves represent the $\mathrm{H}_{2} \mathrm{~S}$ accumulated in alum sludge. In general, sorption performance showed that in the initial test period, sorption occurred rapidly, and then slowed to gradually reach a flat stage with time under all three flow rates. The minimum flow rate ( $3 \mathrm{~L} / \mathrm{h}$ ) obtained the largest fixed quantity of $95.9 \mathrm{mg}$ for $0.5 \mathrm{~g}$ of alum sludge, which is $191.8 \mathrm{mg} \mathrm{H} \mathrm{H}_{2} \mathrm{~S} / \mathrm{g}$ alum sludge at $200 \mathrm{~h}$. In particular, the flow rate of $3 \mathrm{~L} / \mathrm{h}$ showed the best performance from the beginning of sorption. However, after about $133 \mathrm{~h}$, the quantity of $3 \mathrm{~L} / \mathrm{h}$ accumulated $\mathrm{H}_{2} \mathrm{~S}$ was over that of $5 \mathrm{~L} / \mathrm{h}$ accumulated $\mathrm{H}_{2} \mathrm{~S}$. The adsorption capacity revealed no significant dependence on the flow rate, for example, at $200 \mathrm{~h}$, the accumulated $\mathrm{H}_{2} \mathrm{~S}$ on $0.5 \mathrm{~g}$ alum sludge under $3,4,5 \mathrm{~L} / \mathrm{h}$ was $95.7,72.2,82.9 \mathrm{mg}$, respectively. In addition, for the $0.5 \mathrm{~g}$ alum sludge trials under $5 \mathrm{~L} / \mathrm{h}$, it has been repeated three times to check repeatability. This is an expected outcome as the adsorption capacity does not depend on the flow rate. Indeed, it is an intrinsic characteristic of the sorbent.

To test the effect of the sorbent quantity on the sorption performance, the amount of alum sludge was increased while the gas flow rate remained unchanged. Fig. 3 shows the results obtained with $0.5 \mathrm{~g}$ and $1.0 \mathrm{~g}$ alum sludge, which corresponded to the 0.5 and $1.1 \mathrm{~cm}$ bed height under $5 \mathrm{~L} / \mathrm{h}$ flow rate. It was observed that the accumulated $\mathrm{H}_{2} \mathrm{~S}$ on $0.5 \mathrm{~g}$ and $1.0 \mathrm{~g}$ alum sludge at $215 \mathrm{~h}$ are $82.9 \mathrm{mg}$ ( $165.8 \mathrm{mg} \mathrm{H} \mathrm{H}_{2} \mathrm{~S} / \mathrm{g}$ alum sludge) and $235.4 \mathrm{mg} \mathrm{H}_{2} \mathrm{~S} / \mathrm{g}$ alum sludge, respectively. The increase of alum sludge quantity improved

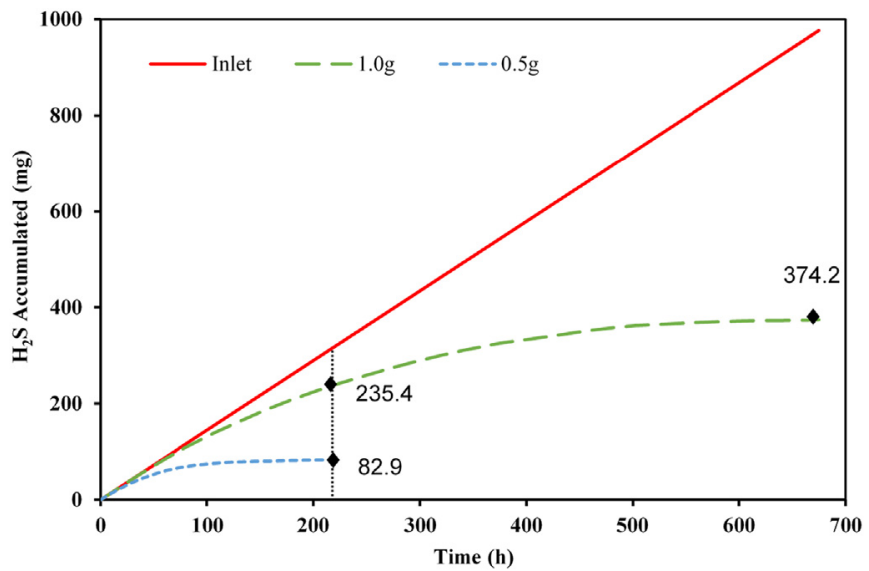

Fig. 3. Quantity of the $\mathrm{H}_{2} \mathrm{~S}$ fed into the reactor (Inlet curve) and fixed on different mass of alum sludge under $5 \mathrm{~L} / \mathrm{h}$ flow rate.
$\mathrm{H}_{2} \mathrm{~S}$ removal, contact time was a crucial parameter for $\mathrm{H}_{2} \mathrm{~S}$ removal. At about $667 \mathrm{~h}$, the accumulated $\mathrm{H}_{2} \mathrm{~S}$ was $374.2 \mathrm{mg} \mathrm{H}_{2} \mathrm{~S} / \mathrm{g}$ of alum sludge. The capacity of the alum sludge-based sorbent is much higher than the majority sorbents, e.g., pyrolysis char $=57.6 \mathrm{mg}$ $\mathrm{H}_{2} \mathrm{~S} / \mathrm{g}$ (Hervy et al., 2018), $\mathrm{Fe}_{2} \mathrm{O}_{3}$-based sorbent $=17.1 \mathrm{mg} \mathrm{H}_{2} \mathrm{~S} / \mathrm{g}$ (Long and Loc, 2016), and sewerage sludge-based sorbents $=8.63 \mathrm{mg} \mathrm{H} \mathrm{H}_{2} \mathrm{~S} / \mathrm{g}$ (Gutiérrez Ortiz et al. 2014). This may be due to alum sludge specific surface area and pore structural differences. The alum sludge presents microporous structure, with sorption occurring in these pore sites (Yan et al., 2004). Furthermore, the various metals (e.g., $\mathrm{Al}, \mathrm{Ca}, \mathrm{Mg}, \mathrm{Fe}$ ) contained in the alum sludge could possibly facilitate $\mathrm{H}_{2} \mathrm{~S}$ adsorption (Hervy et al., 2018).

\subsection{Breakthrough through curves modeling}

\subsubsection{Model parameters}

Breakthrough curve and breakthrough time are vital factors for operation and dynamic description of an adsorption process (Dong and Zhao, 2018). In order to explain the dynamic adsorption behavior and to scale it up for industrial application, Thomas, BDST and Yoon-Nelson models were utilized. The determined relative constants and correlation coefficients for all three models are shown in Table 1 . All the model constants $\left(\mathrm{K}_{\mathrm{Th}}, \mathrm{K}, \mathrm{K}_{\mathrm{YN}}\right)$ increased with the decreasing of sorbent height, which likely due to the increase in mass transfer resistance (Gutiérrez Ortiz et al. 2014; Rout et al., 2017). By increasing the flow rate, the value of $K_{\mathrm{Th}}$ increased and $\mathrm{q}_{0}$ decreased, which attributed to the lower empty bed contact time (EBCT) resulting in insufficient contact between the adsorbate with the available active sites on the sorbent.

The correlation coefficients $\mathrm{R}^{2}$ of Thomas, BDST, and $\mathrm{Y}-\mathrm{N}$ models were $0.90,0.93,0.91$, respectively, under $1 \mathrm{~g}$ alum sludge and $5 \mathrm{~L} / \mathrm{h}$ flow rate, while Thomas model has the highest $\mathrm{R}^{2}$ of 0.93 under the $0.5 \mathrm{~g}$ alum sludge and $5 \mathrm{~L} / \mathrm{h}$. However, the $\mathrm{R}^{2}$ the three models were not satisfied under the $0.5 \mathrm{~g}$ alum sludge $4 \mathrm{~L} / \mathrm{h}$ condition. This is due to the experiment data turbulence and could not fit well with the models. As shown in Fig. 4 (b), the experimental data slightly deviate from a model line, suggesting the complex nature of the $\mathrm{H}_{2} \mathrm{~S}$ adsorption process by alum sludge, which might be due to more than one rate limiting step (Rout et al., 2017). Additionally, the Thomas, BDST, and Y-N models' $\mathrm{R}^{2}$ under the $0.5 \mathrm{~g}$ alum sludge and $3 \mathrm{~L} / \mathrm{h}$ condition were $0.9,0.93,0.92$, respectively, indicating that all three models accurately predicate $\mathrm{H}_{2} \mathrm{~S}$ breakthrough.

The simulated breakthrough curves as well as experimental data are presented in Fig. 4. The capacity of the sorbent determined the general position of breakthrough curve, with respect to sorbent height and flow rate. Apart from the breakthrough part of Fig. 4 (a) and initial part of (d), and compared with correlation coefficients, all Thomas, BDST and $\mathrm{Y}-\mathrm{N}$ models can better describe the adsorption behavior. The $50 \%\left(C_{t} / C_{0}=0.5\right)$ experimental breakthrough time and their corresponding simulated time by the three models were calculated and presented (Table S2). The Thomas, BDST and Y-N models could predict the breakthrough time of $0.5 \mathrm{~g}$ alum sludge under $3 \mathrm{~L} / \mathrm{h}$ with the same $2.0 \%$ deviation. However, the deviation was $28.3,33.3,34.5 \%$ when those models were applied to $0.5 \mathrm{~g}$ alum sludge under $4 \mathrm{~L} / \mathrm{h}$ condition. This may be due to the turbulence of experimental time data around 50\% breakthrough capacity. As shown in Fig. 4 (b), the turbulence of the data makes the three simulation curves behind of the experimental time. Regarding the $0.5 \mathrm{~g}$ alum sludge under $5 \mathrm{~L} / \mathrm{h}$ flow rate, the prediction of Thomas model was the best (deviation of $1.9 \%$ ), compared to the BDST model (3.6\%) and Y-N model (5.4\%). In addition, among the three models, the BDST model could well predicate the $1.0 \mathrm{~g}$ alum sludge under $5 \mathrm{~L} / \mathrm{h}$, with the lowest deviation of $3.1 \%$. 
Table 1

Model parameters calculation.

\begin{tabular}{|c|c|c|c|c|c|c|c|c|c|c|c|}
\hline $\mathrm{C}_{0}(\mathrm{mg} / \mathrm{kg})$ & $\mathrm{m}(\mathrm{kg})$ & $\mathrm{Q}(\mathrm{L} / \mathrm{min})$ & $\mathrm{K}_{\mathrm{Th}}\left(\mathrm{m}^{3} / \mathrm{kg}-\mathrm{min}\right)$ & $\mathrm{q}_{0}(\mathrm{~kg} / \mathrm{L})$ & $\mathrm{R}^{2}$ & $\mathrm{~K}(\mathrm{~L} / \mathrm{kg}-\mathrm{min})$ & $\mathrm{N}_{0}(\mathrm{~kg} / \mathrm{L})$ & $\mathrm{R}^{2}$ & $\mathrm{~K}_{\mathrm{YN}}\left(\mathrm{min}^{-1}\right)$ & $\tau(\min )$ & $\mathrm{R}^{2}$ \\
\hline 200 & 0.001 & 0.083 & 0.4612 & 0.235 & 0.90 & 0.5 & 0.222 & 0.93 & 0.0001 & 14477.9412 & 0.91 \\
\hline 200 & 0.0005 & 0.083 & 1.9765 & 0.107 & 0.93 & 2.3 & 0.108 & 0.89 & 0.0006 & 3301.3600 & 0.85 \\
\hline 200 & 0.0005 & 0.067 & 1.3835 & 0.083 & 0.78 & 1.1 & 0.090 & 0.75 & 0.0004 & 3537.1429 & 0.70 \\
\hline 200 & 0.0005 & 0.050 & 1.4165 & 0.124 & 0.90 & 1.4 & 0.118 & 0.93 & 0.0004 & 5930.2326 & 0.92 \\
\hline
\end{tabular}
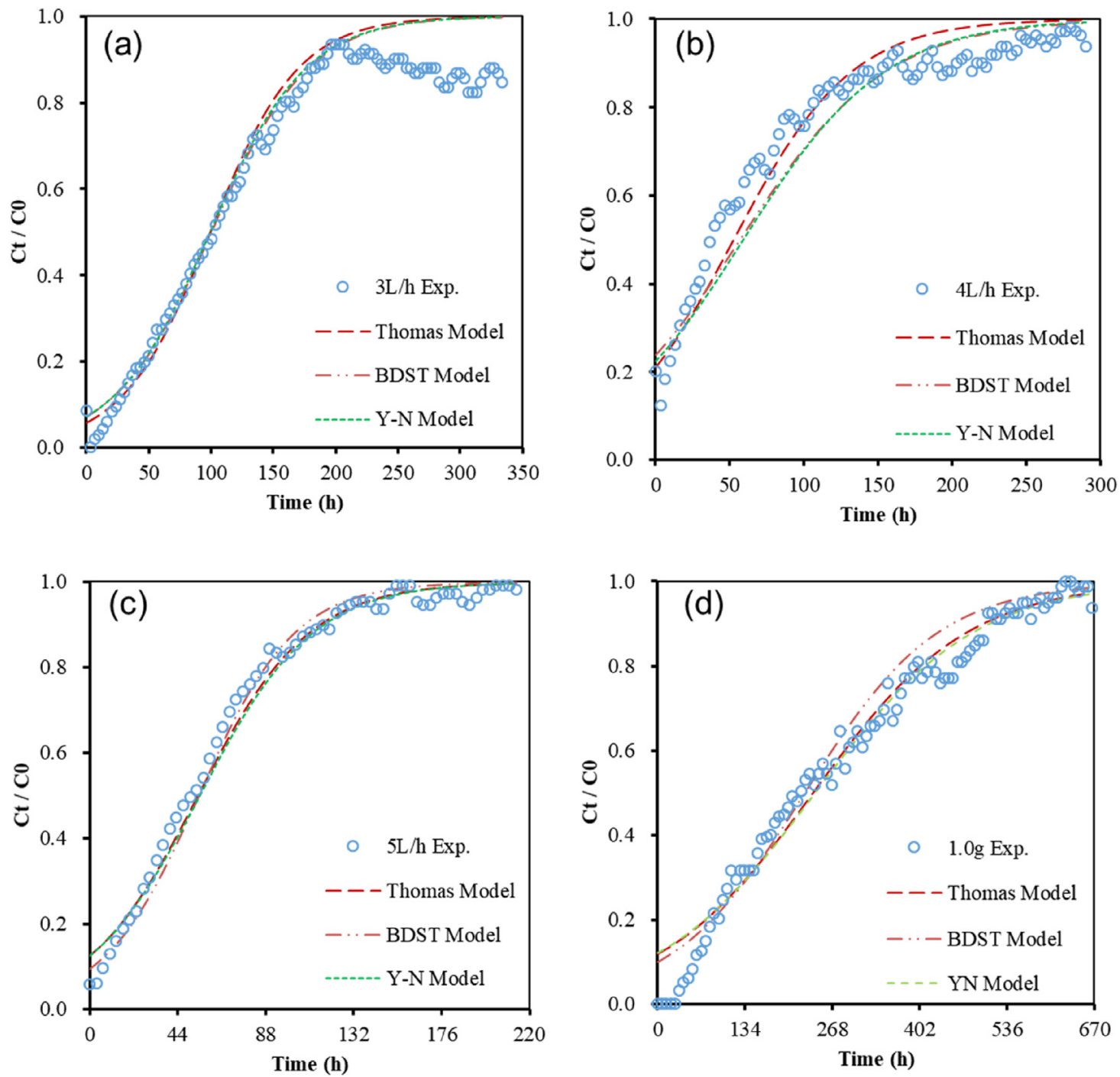

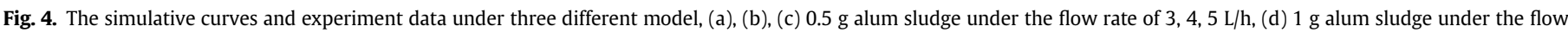
rate of $5 \mathrm{~L} / \mathrm{h}$.

\subsubsection{Effect of flow rate}

Fig. 4 (a), (b), (c) show the effects of flow rate $(3,4$ and $5 \mathrm{~L} / \mathrm{h}$, respectively) on the sorption, keeping constant the inlet $\mathrm{H}_{2} \mathrm{~S}$ concentration (200 ppmv) and the alum sludge mass ( $0.5 \mathrm{~g})$. The flow rate represents the major influence in the shape of the breakthrough curve. By increasing the flow rate from 3 to $5 \mathrm{~L} / \mathrm{h}$, a decrease in both breakthrough and exhaustion times occurred from 350 to $220 \mathrm{~h}$. The lower flow rate presented a longer breakthrough time, reflecting a wider mass transfer zone. Moreover, the results also indicated that by increasing the flow rate at a constant bed height (mass), the breakthrough time tend to become lower. For example, for $\mathrm{m}=0.5 \mathrm{~g}, \mathrm{H}_{2} \mathrm{~S}$ adsorption saturation time varied from 200 to $151.7 \mathrm{~h}$ with the flow rate increasing from 3 to $5 \mathrm{~L} / \mathrm{h}$.
Increasing flow rates result in a lower residence time. It also weaken the $\mathrm{H}_{2} \mathrm{~S}$ interaction with alum sludge and disturbed the intraparticle mass transfer between the $\mathrm{H}_{2} \mathrm{~S}$ and the alum sludge (Zheng et al., 2017). Intra-particulate diffusion has been treated as the rate limiting step of adsorption process. Decreasing the flow rate could facilitate the intra-particular diffusion (Aguilera and Gutiérrez Ortiz, 2016; Arim et al., 2018). Furthermore, a more $\mathrm{H}_{2} \mathrm{~S}$-alum sludge interaction and higher diffusion of $\mathrm{H}_{2} \mathrm{~S}$ onto alum sludge could make use of the maximal percentage of the bed, which improved the column performance. Similar trends have been reported by other researchers using different sorbents (e.g., $\mathrm{Fe}_{2} \mathrm{O}_{3}$ based sorbent and dolochar) (Long and Loc, 2016; Rout et al., 2017). Additionally, in Fig. 4 (a), the differences of experimental data and 
three dynamic adsorption model curves observed near the breakthrough point can be attributed to lower concentration gradient between adsorbate in the sorbent surface and in the bulk phase. Similar phenomenon was reported by de Franco et al. (de Franco et al., 2018) by using activated carbon for diclofenac removal from water in a fixed-bed column. The lower flow rate showed flatter breakthrough profiles, with a more extended breakthrough zone.

\subsubsection{Effect of bed height}

Fig. 4 (c) and (d) present the effects of bed height $(0.5$ or $1.1 \mathrm{~cm})$ on $\mathrm{H}_{2} \mathrm{~S}$ sorption. Increasing the bed height from 0.5 to $1.1 \mathrm{~cm}$ resulted in an increase in both breakthrough and exhaustion times from 220 to $670 \mathrm{~h}$. However, contrary to the effect of the flow rate, as the bed depth increases, the breakthrough and the saturation time also increase, resulting in a greater operating time to take the column to the exhaustion point. By increasing bed height, the slope of the breakthrough curves became flatter, result in a longer mass transfer zone (MTZ). This is because the quantity of alum sludge was increased, more binding sites were available for sorption (Ahmed and Hameed, 2018). For a lower bed height, the mass transfer was controlled by the axial dispersion phenomena, result in a reduction of the diffusivity of $\mathrm{H}_{2} \mathrm{~S}$. Thus, $\mathrm{H}_{2} \mathrm{~S}$ does not have enough time to diffuse into the alum sludge, allowing $\mathrm{H}_{2} \mathrm{~S}$ leaving the column earlier. On the other hand, the contact time between the $\mathrm{H}_{2} \mathrm{~S}$ and the alum sludge is higher when the bed depth increases (Rout et al., 2017). Similar types of results have already been reported in earlier researches (Aguilera and Gutiérrez Ortiz, 2016; de Franco et al., 2018; Long and Loc, 2016).

\subsection{Adsorption mechanisms of $\mathrm{H}_{2} \mathrm{~S}$ onto alum sludge}

\subsubsection{Sorbent characteristics before and after the adsorption trials}

As shown in Table 2, S increased from 0 to $34,981 \mathrm{mg} / \mathrm{kg}$ after sorption, suggesting that $\mathrm{H}_{2} \mathrm{~S}$ was sorbed onto alum sludge. During the $\mathrm{H}_{2} \mathrm{~S}$ removal trials, the alum sludge $\mathrm{pH}$ decreased from 10 to 7.5 . The $\mathrm{pH}$ decreasing from 10 to neutral was likely due to the dissolution of $\mathrm{H}_{2} \mathrm{~S}$ in moist surface of the alum sludge and formation of sulfuric acid. It also suggested that the presence of air promoted the formation of acidic species, resulted in the acidification of sorbent (alum sludge) surface (Hervy et al., 2018). Nevertheless, the pH decrease seemed insignificant compared with the results in the literature. E.g., Bandosz (2002) reports that a pH decreasing from 9.7 to 2.8 when using the moist activated char for $\mathrm{H}_{2} \mathrm{~S}$ removal from. It suggested that the formation of sulfur oxide species is relatively low in the current study.

It has been pointed out by Yan et al. (2004) that pH has impact on the efficacy of $\mathrm{H}_{2} \mathrm{~S}$ dissociation and oxidation. The dissociation of $\mathrm{H}_{2} \mathrm{~S}$ prefers the basic $\mathrm{pH}$. By accumulating of $\mathrm{HS}^{-}$ions, they were oxidized to sulfur polymers (Bandosz, 2002). On the contrary, the moderately or acid sorbent is believed to inhibit the dissociation of $\mathrm{H}_{2} \mathrm{~S}$ and the creation of $\mathrm{H}_{2} \mathrm{~S}$ ions. After the sulfuric acid is formed, these ions are oxidized to sulfur oxides (in low concentration and small pores). In the literature, a threshold value of $\mathrm{pH} 4.5$ was proposed (Yan et al., 2004). If $\mathrm{pH}$ is below 4.5, only physical adsorption could occur, and the concentration of dissociated $\mathrm{H}_{2} \mathrm{~S}$

Table 2

Elemental analysis and $\mathrm{pH}$ of the sorbent.

\begin{tabular}{lll}
\hline Characteristics & Alum sludge & Exhausted alum sludge \\
\hline $\mathrm{pH}$ & 10.0 & 7.5 \\
$\mathrm{~S}(\mathrm{mg} / \mathrm{kg})$ & 0 & 34,981 \\
$\mathrm{C}(\%)$ & 30.7 & 20.0 \\
$\mathrm{~N}(\%)$ & 0.5 & 0.5 \\
\hline
\end{tabular}

ions is negligible.

As such, the adsorption process of alum sludge was dominated by chemisorption as the $\mathrm{pH}$ value of alum sludge is 10 . The $\mathrm{H}_{2} \mathrm{~S}$ first and second dissociation $\mathrm{pK}_{\mathrm{a}}$ constants are 7.2 and 14 , respectively. Thus, $\mathrm{HS}^{-}$ions will be at high concentration, resulting in the formation of polysulfides. Along with the reaction progressed, $\mathrm{pH}$ will decrease and change from caustic to neutral.

It can be seen from Table 3 that alum sludge presents a greater micropore volume and surface area. The pore structural properties of alum sludge were significantly modified during the $\mathrm{H}_{2} \mathrm{~S}$ removal trials. The adsorption process reduces the micropore volume as well as the surface area $\left(S_{p}\right)$ of alum sludge. The microporous volume of alum sludge was zero after the adsorption trials, which can be explained by the higher amount of $\mathrm{H}_{2} \mathrm{~S}$ adsorbed by alum sludge in these pores.

In addition, the average pore diameter of alum sludge also increases from $2.4 \mathrm{~nm}$ to $5.3 \mathrm{~nm}$ by $\mathrm{H}_{2} \mathrm{~S}$ adsorption process. This could suggest that adsorption takes place in most of the smaller diameter pores. As these pores are getting less and less, the number of pores with a greater diameter remains stable. The average overall pore diameter value measured is based on the nitrogen adsorption test, which was carried out on the exhausted alum sludge sorbent. Similar observations were also made by de Falco et al. (2018), Hervy et al. (2018), and Sigot et al. (2016). Yan et al. (2004) states that the physical conditions for $\mathrm{H}_{2} \mathrm{~S}$ adsorption and oxidation require the pores containing functional groups and small enough when at low humidity a water film could be created, and this seems in the range between the $0.5-1 \mathrm{~nm}$ region. In addition, by heating the exhausted alum sludge to $200{ }^{\circ} \mathrm{C}$, the relevant $S_{p}$ and the microporous volume were increase. It suggested that the $\mathrm{H}_{2} \mathrm{~S}$ is desorbed. The exhausted alum sludge could potentially be used again by thermal regeneration, further studies would be warranted.

The SEM-EDX image in Fig. 5 was obtained from the exhausted alum sludge. The EDX peaks clearly show adsorbed sulfur, confirming $\mathrm{H}_{2} \mathrm{~S}$ sorption onto alum sludge (Nam et al., 2018). Regarding the other element analysis, it was in accordance with the ICP results (Table S1), as well as the TEM-EDX image which is presented in Fig. 6.

It can be seen from Fig. 6, the exhausted alum sludge contained various metals such as $\mathrm{Al}, \mathrm{Ca}, \mathrm{Fe}, \mathrm{Mg}$. In addition, $\mathrm{C}, \mathrm{Si}$ and $\mathrm{O}$ were also found on the surface of exhausted alum sludge, which was corresponding with the abovementioned ICP and SEM-EDX result. Apart from that, $S$ was observed and it was homogeneously distributed throughout the alum sludge surface. Noteworthy, the S distribution appears to be correlated with $\mathrm{Fe}, \mathrm{Ca}, \mathrm{Mg}$, and $\mathrm{O}$ distribution. This indicates that $\mathrm{H}_{2} \mathrm{~S}$ sorption was likely preferred on alum sludge metal oxide species. The reaction between various metal oxide species with $\mathrm{H}_{2} \mathrm{~S}$ could produce metal sulfides (de Falco et al., 2018). Additionally, alum sludge O-containing groups could have triggered an $\mathrm{H}_{2} \mathrm{~S}$ oxidation reaction and increased the $\mathrm{H}_{2} \mathrm{~S}$ removal capacity (Hervy et al., 2018).

\subsubsection{Identification of sulfur products}

To go further in the identification of the gas removed during the thermal treatment, sulfur species coupled with MS analyses were performed with raw and used alum sludge. Fig. 7 shows the derivative thermogravimetric (DTG) curves and the releasing of the effluent. Based on literature data (Hervy et al., 2018; Nam et al., 2018; Yan et al., 2004; Zeng et al., 2018), there are two temperature ranges for sulfur compound desorption, while the corresponding releasing gas provides clues on the nature of these compounds: 1) In the first zone (highlighted in green in Fig. 7) between 200 and $350^{\circ} \mathrm{C}$, a SO 2 release suggested the desorption of physisorbed $\mathrm{SO}_{2}$ or other sulfur oxides, while a $\mathrm{H}_{2} \mathrm{~S}$ release reveals the decomposition of metallic sulphides; 2) In the second zone 
Table 3

Structural properties of alum sludge.

\begin{tabular}{|c|c|c|c|c|c|c|}
\hline Samples & $\mathrm{S}_{\mathrm{P}}(\mathrm{BET})\left(\mathrm{m}^{2} / \mathrm{g}\right)$ & $\mathrm{S}_{\text {mic }}\left(\mathrm{m}^{2} / \mathrm{g}\right)$ & $\mathrm{V}_{\text {mic }}\left(\mathrm{cm}^{3} / \mathrm{g}\right)$ & $\mathrm{V}<2 \mathrm{~nm}\left(\mathrm{~cm}^{3} / \mathrm{g}\right)$ & $\mathrm{V}<25 \mathrm{~nm}\left(\mathrm{~cm}^{3} / \mathrm{g}\right)$ & $\mathrm{d}_{\text {pore }} \mathrm{nm}$ \\
\hline Alum sludge & $238\left(105^{\circ} \mathrm{C}\right)$ & 119.56 & 0.05 & 0.082 & 0.237 & $2.4-3.2-5.0$ \\
\hline \multirow[t]{3}{*}{ Exhausted alum sludge } & $65\left(105^{\circ} \mathrm{C}\right)$ & 1.74 & 0.00 & 0.015 & 0.136 & $3.3-5.3$ \\
\hline & $111\left(150^{\circ} \mathrm{C}\right)$ & 29.13 & 0.01 & 0.033 & 0.154 & $2.4-3.2-5.0$ \\
\hline & $198\left(200^{\circ} \mathrm{C}\right)$ & 93.45 & 0.04 & 0.069 & 0.195 & $2.4-3.2-5.0$ \\
\hline
\end{tabular}
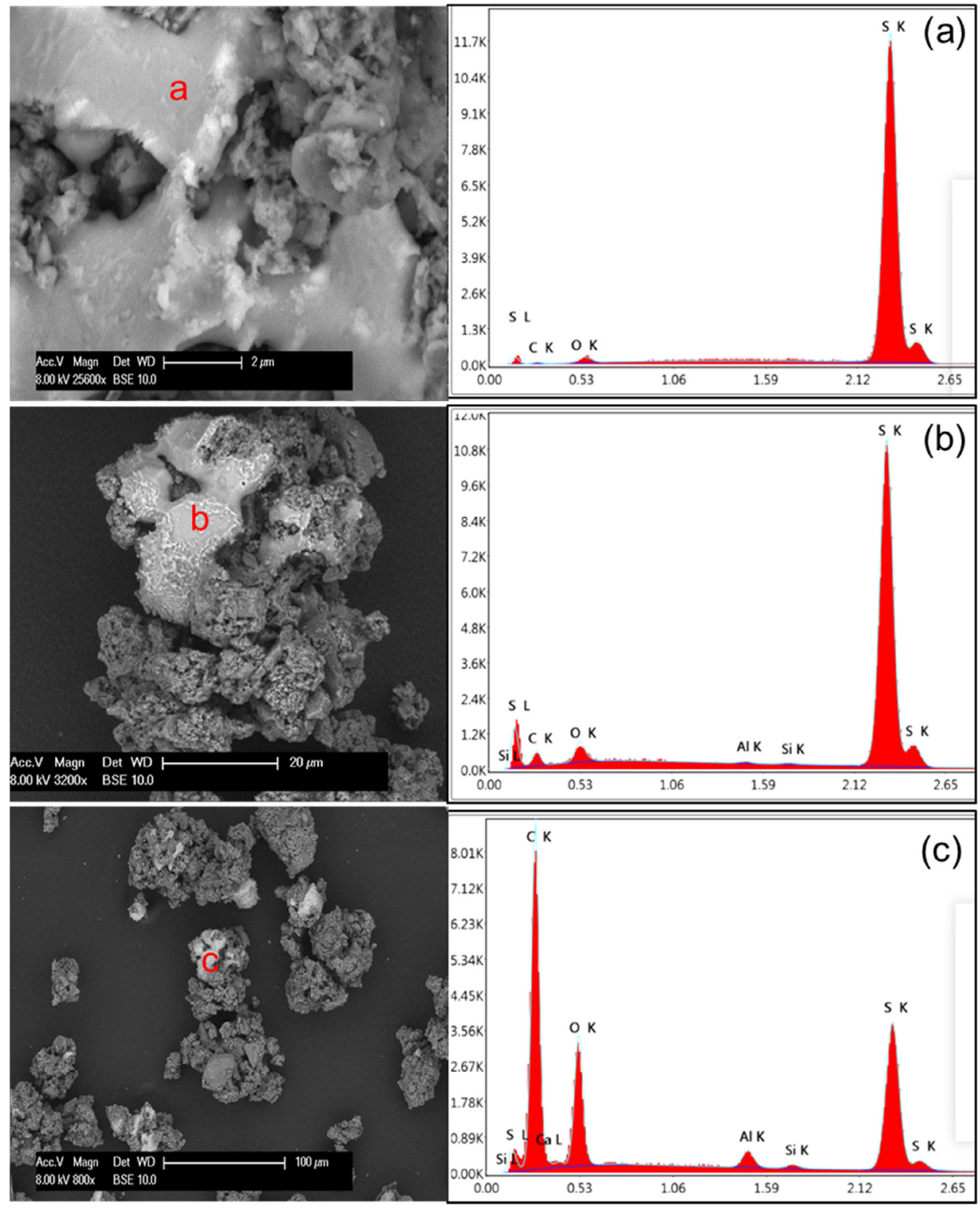

Fig. 5. SEM-EDX of the exhausted alum sludge.

(highlighted in orange in Fig. 7) between 350 and $600{ }^{\circ} \mathrm{C}$, a release of $\mathrm{SO}_{2}$ reflects the decomposition of sulfur radicals and/or elemental sulfur, while a release of $\mathrm{H}_{2} \mathrm{~S}$ indicates the decomposition of polysulfides. 

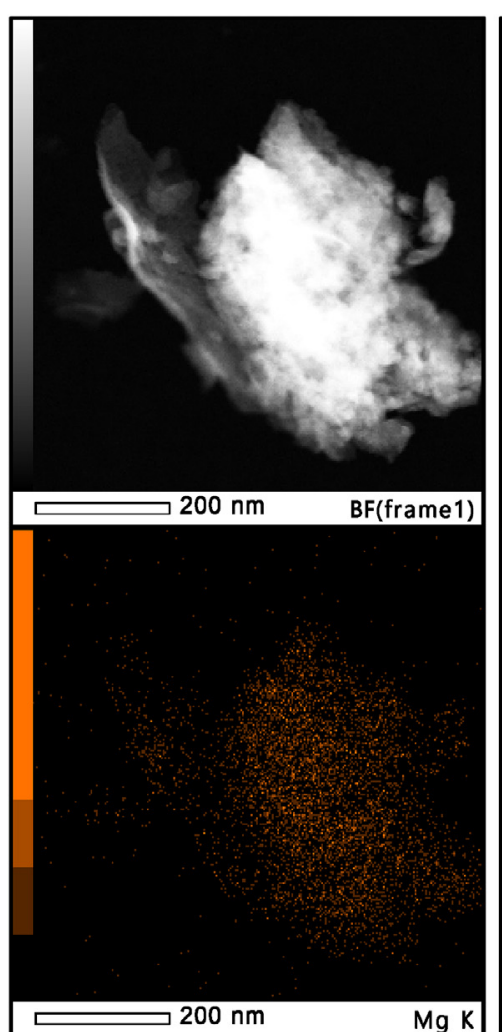

$\mathrm{Mg} \mathrm{K}$

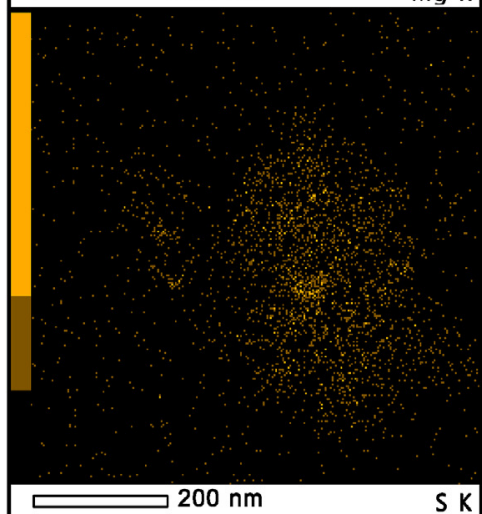

S K
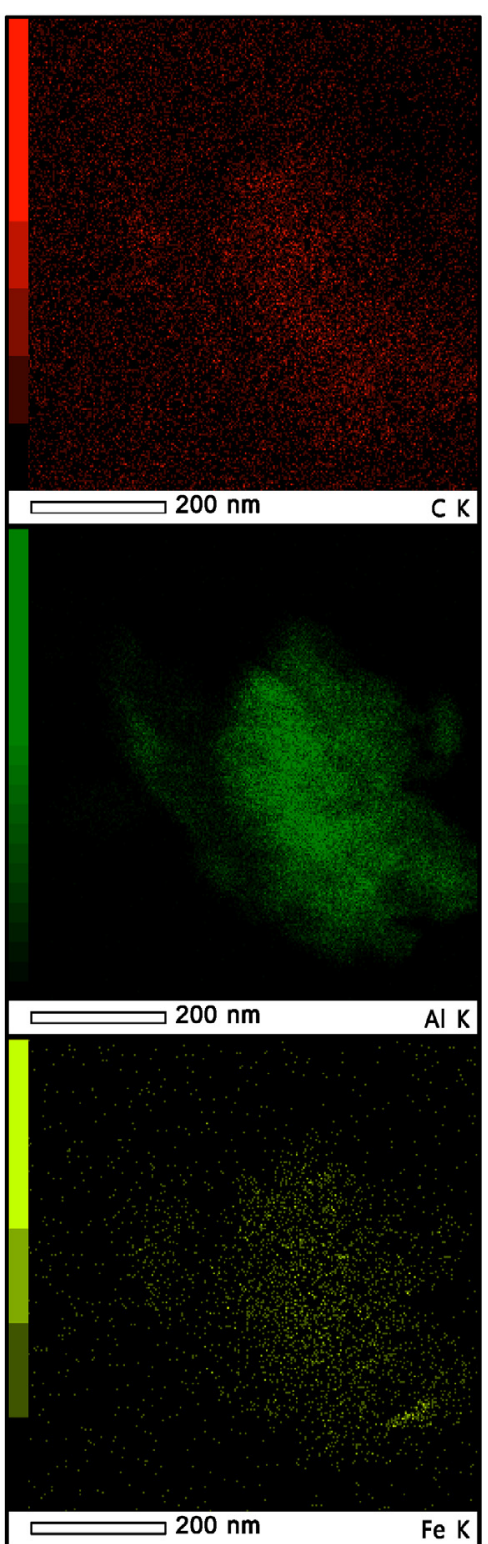
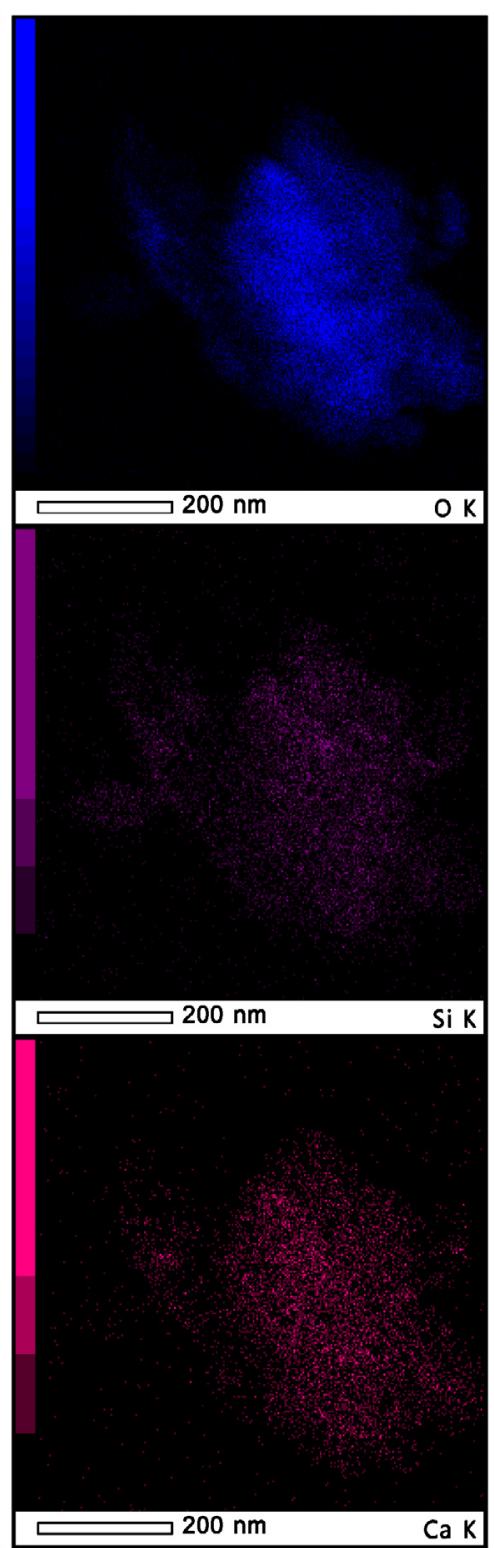

Fig. 6. TEM-EDX images of the exhausted alum sludge sorbent.

As shown in Fig. 7, the DTG curves of both raw and exhausted alum sludge present two prominent peaks at around 110 and $300{ }^{\circ} \mathrm{C}$. The peak at $110^{\circ} \mathrm{C}$, corresponds to dehydration processes as well as the desorption of weakly adsorbed $\mathrm{H}_{2} \mathrm{~S}$ (Zeng et al., 2018). The weight loss of exhausted and raw alum sludge in this stage was 20.8 and 6.7\%, respectively. However, the second DTG peaks (around $300^{\circ} \mathrm{C}$ ) of exhausted alum sludge were wider than the DTG peak curve of raw alum sludge. The weight loss of exhausted and raw alum sludge in this stage was 21.7 and 3.1\%, respectively. This was in agreement with the ICP results. Moreover, the mass lost between raw and exhausted sorbent was $31.7 \%$. From the ICP analysis, the increased $\mathrm{S}$ in exhausted sorbent was 33.5\%. This represents the removal of $\mathrm{SO}_{2}$ from the decomposition of oxysulfur acids or $\mathrm{H}_{2} \mathrm{~S}$ from decomposition of alkali metal sulfides, while the peak at $350-600{ }^{\circ} \mathrm{C}$ is probably the result of the desorption of elemental sulfur and decomposition of the surface reaction products (Siriwardane et al., 2017).

The Mass Spectrometry analyses coupled with the thermal analyzes allows identification of the gas associated with a thermal transformation of the solid. For exhausted alum sludge, the first mass loss occurred at $310^{\circ} \mathrm{C}$, while a release of $\mathrm{H}_{2} \mathrm{~S}$ (red curve) and $\mathrm{SO}_{2}$ (orange curve) was observed. The second peak at $510{ }^{\circ} \mathrm{C}$ corresponding to a release of $\mathrm{H}_{2} \mathrm{~S}, \mathrm{SO}_{2}$ and $\mathrm{CO}_{2}$, it indicates the resultant products are sulfur radicals, elemental sulfur, and/or metal sulfides (Bandosz, 2002; Hervy et al., 2018; Yan et al., 2002). This behavior (e.g., mass loss at $310^{\circ} \mathrm{C}$ and a simultaneous release of $\mathrm{H}_{2} \mathrm{~S}$ and $\mathrm{SO}_{2}$ ) also suggested that the resultant sulfur products formed on alum sludge were sulfur oxide species, alkali metal sulfides $\left(310-350{ }^{\circ} \mathrm{C}\right)$, sulfur radicals, elemental sulfur $\left(\mathrm{SO}_{2}\right.$ release from 350 to $\left.500{ }^{\circ} \mathrm{C}\right)$, polysulfides and/or metal sulfides $\left(\mathrm{H}_{2} \mathrm{~S}\right.$ release from 350 to $500{ }^{\circ} \mathrm{C}$ ). Previously published works have shown similar observations (Sigot et al., 2016; Siriwardane et al., 2017; Zeng et al., 2018), which established that the first peak in the range of $200-600{ }^{\circ} \mathrm{C}$ was likely the oxidized sulfur desorption, while the second peak was the elemental sulfur components.

The exact locations of the two DTG peaks vary in temperature from literature. The study carried out by Yan et al. (2002) showed the DTG peaks of the exhausted sorbent were at around 290 and 

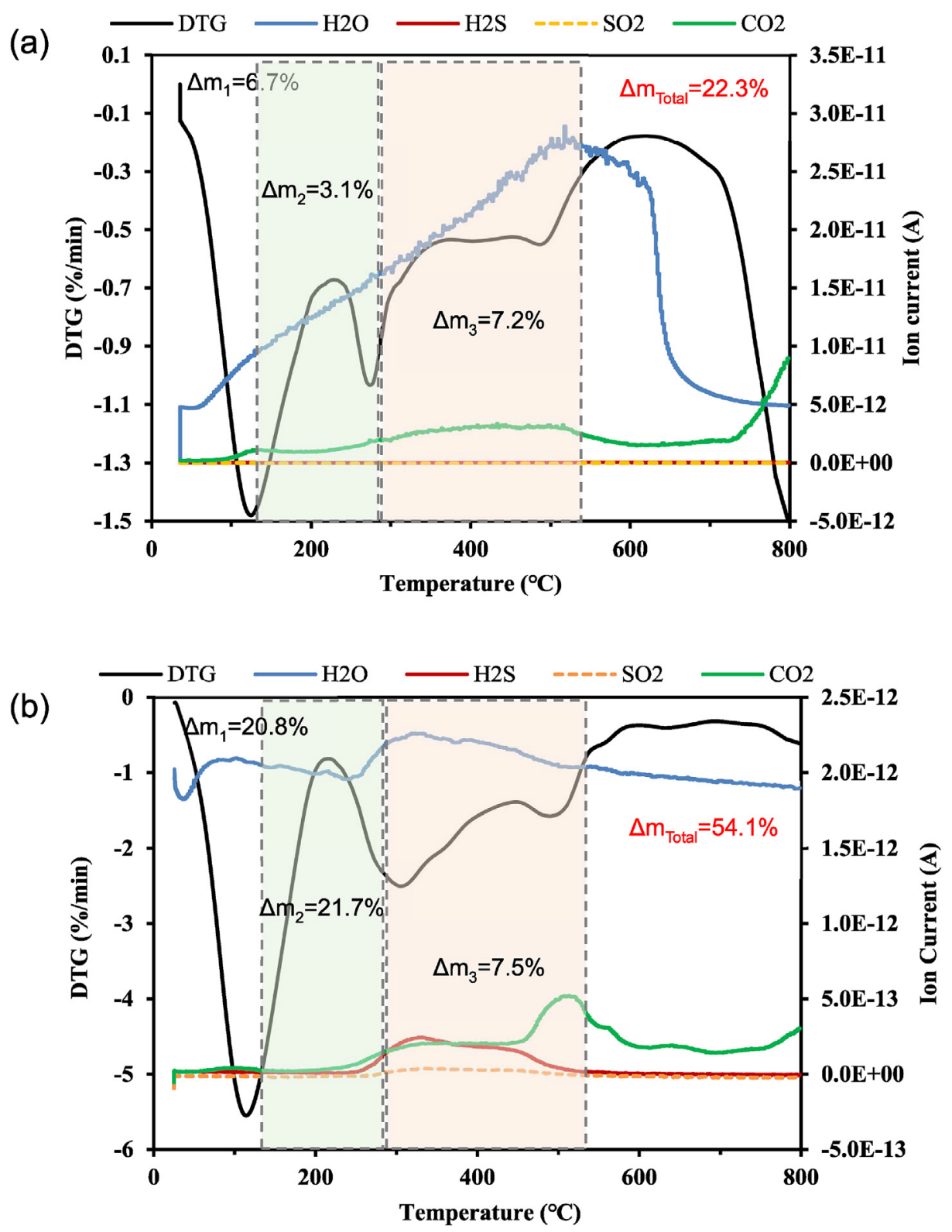

Fig. 7. TGA-MS analysis of raw alum sludge before (a) and after (b) the adsorption trials.

$530^{\circ} \mathrm{C}$, while in the study of Hervy et al. (2018) the two DTG peaks were at 285 and $370{ }^{\circ} \mathrm{C}$. Both studies agree that the peak relative to the elemental sulfur is behind sulfur oxides peak. The DTG peaks occur at different temperatures is due to the various physicochemical characteristics of the sorbent. Yan et al. (2004) pointed out that the sulfur oxides were more soluble than elemental sulfur. Washing could be applied on the exhausted sorbents to check the differences in their thermal desorption pattern, and this could be the form about another study regarding $\mathrm{H}_{2} \mathrm{~S}$ adsorption onto alum sludge.

The presence of various forms of sulfur compounds in addition to the oxides of sulfur on the surface of alum sludge after $\mathrm{H}_{2} \mathrm{~S}$ adsorption indicates that chemical reactions are involved in $\mathrm{H}_{2} \mathrm{~S}$ retention. The alkaline and chemical promoter presence on the surface and water facilitated dissociation, dimerization and oxidation reactions.
3.4.3. Proposed mechanisms of $\mathrm{H}_{2} \mathrm{~S}$ removal by alum sludge

The various resultant sulfur compounds suggested that the sorption process of $\mathrm{H}_{2} \mathrm{~S}$ on alum sludge consists of a complex reaction. This is likely due to the presence of various reactive sites, such as carbon, metal oxides and carbonates (Bamdad et al., 2018; Hervy et al., 2018). Based on these data, the following reactions (Fig. 8) proposed are expected to occur during alum sludge $\mathrm{H}_{2} \mathrm{~S}$ sorption.

When the sorption process begins and $\mathrm{H}_{2} \mathrm{~S}$ molecules are located on alum sludge active sites, alum sludge humidity/moisture can dissociate the $\mathrm{H}_{2} \mathrm{~S}$ (Hervy et al., 2018):

$H_{2} S \Leftrightarrow^{K \alpha 1} H^{+}+H S^{-} \Leftrightarrow^{K \alpha 2} 2 H^{+}+S^{2-}$

with $\mathrm{K}_{\alpha 1}=10^{-7}$ and $\mathrm{K}_{\alpha 2}=10^{-13}$. When the $\mathrm{pH}$ is basic, the HS concentration is relatively greater, which forces the created sulfur atoms to be close to each other, capable of creating polysulfides. 


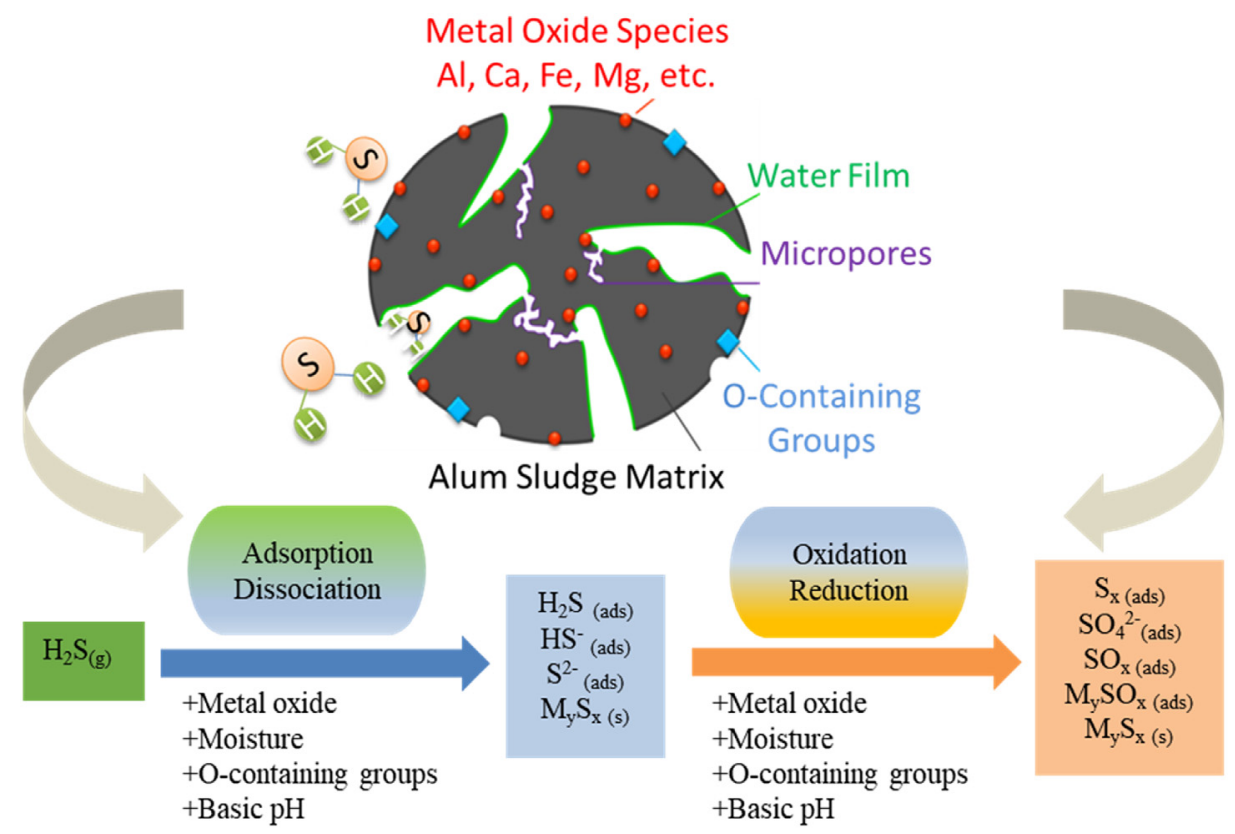

Fig. 8. Mechanisms of $\mathrm{H}_{2} \mathrm{~S}$ adsorption onto alum sludge.

Secondly, $\mathrm{H}_{2} \mathrm{~S}$ reacts with the alum sludge-containing metal oxide species $\left(\mathrm{MO}_{\mathrm{x}}\right)$ to produce metal sulfides $\left(\mathrm{MS}_{\mathrm{x}}\right)$ (Hervy et al., 2018; Wu et al., 2018). Thereafter, the metal sulfur oxidation with oxygenated organic and inorganic species leads to the formation of metal sulphate (Bandosz, 2002). The reaction could be as follows:

$x \mathrm{H}_{2} \mathrm{~S}_{(\mathrm{g})}+\mathrm{MO}_{x} \Leftrightarrow M S_{x}+x \mathrm{H}_{2} \mathrm{O}$

Lastly, O-containing groups in alum sludge also increase the $\mathrm{H}_{2} \mathrm{~S}$ removal capacity by the $\mathrm{H}_{2} \mathrm{~S}$ oxidation reaction (Yan et al., 2002). In the presence of air, alum sludge surface acidification can be explained by the oxidation of $\mathrm{H}_{2} \mathrm{~S}$ to $\mathrm{H}_{2} \mathrm{SO}_{4}$ (Bandosz, 2002).

$\mathrm{C}(\mathrm{O})+\mathrm{H}_{2} \mathrm{~S}_{(\mathrm{g})} \Leftrightarrow \mathrm{C}(\mathrm{S})+\mathrm{H}_{2} \mathrm{O}$

$\mathrm{H}_{2} \mathrm{~S}+2 \mathrm{O}_{2} \Leftrightarrow \mathrm{H}_{2} \mathrm{SO}_{4}$

\subsection{Determination of the mass transfer coefficient}

The $\mathrm{H}_{2} \mathrm{~S}$ sorption mechanism is governed by external and internal diffusion mass transfer coefficient. Thus, correctly estimating the various mass transfer coefficients is a vital step. To predict the dynamics of the $\mathrm{H}_{2} \mathrm{~S}$ sorption, mathematical models must include the mass-energy balance of the sorbent and the gas phase in the bed as well as an equation for the mass flux (de Franco et al., 2018). The axial dispersion, nonlinear equilibrium behavior, resistance to mass transfer and sorption kinetics are described in terms of partial differential equations, which generally involve a numerical solution (Arim et al., 2018).

Modeling and simulation of empirical models such as Thomas, BDST and the Yoon-Nelson models for $\mathrm{H}_{2} \mathrm{~S}$ adsorption have been investigated. However, these models are based on the assumption that the adsorption rate is limited by the surface reaction. Thus, the current study mainly focuses on the overall mass transfer coefficients determination from the mathematical description of breakthrough curves and their dependency on experimental conditions, which means that the external/internal diffusions are included.

Regarding the adsorption process, $\mathrm{H}_{2} \mathrm{~S}$ molecules are located on the surface of alum sludge. Diffusion mechanisms govern the transport of $\mathrm{H}_{2} \mathrm{~S}$ molecules into the alum sludge pores. In porous materials, diffusion mechanisms are of several types: i) molecular diffusion caused by collisions between molecules, ii) Knudsen diffusion caused by collisions of the molecules with the walls of the pore, iii) surface diffusion caused by the electrostatic forces exerted by the walls on the molecules. Since the alum sludge has microporous structure (Table 3 ). It may be concluded that Knudsen diffusion was the main diffusion mechanism.

In this study, based on the selected parameters (Table S3), the value of tortuosity factor (Gutiérrez Ortiz et al. 2014), the equilibrium constants $\left(\mathrm{K}_{\mathrm{e}}\right)$ calculated by fitting the experimental data, overall mass transfer coefficients are determined for $\mathrm{H}_{2} \mathrm{~S}$ surface diffusivity over interior surface of alum sludge. Results of the mass transfer coefficient from experimental breakthrough fronts at several conditions are shown in Table 4. External and overall mass transfer coefficients are slightly decreased along with flow rate. It should be noted that the external and overall mass transfer coefficients should be the same by using the same sorbent. However, an error of $35 \%$ under the flow rate of $3 \mathrm{~L} / \mathrm{h}$ could be caused by the slow flow rate, leading to a very long saturation time $(667 \mathrm{~h})$. The Knudsen diffusion contributes to internal diffusion (Ahmed and Hameed, 2018); however, this contribution is very small compared to the contribution of external diffusion.

In addition, the Knudsen, Molecular, Effective and Pore diffusivity remained the same under different flow rate and mass of sorbent. This indicates that sorption mechanisms were the same regardless of the experimental conditions.

\section{Perspectives}

Alum sludge as an easily, largely available by-product of water purification processes was firstly reused for $\mathrm{H}_{2} \mathrm{~S}$ abatement. From this study, alum sludge $\mathrm{H}_{2} \mathrm{~S}$ adsorption capacity is relatively good compared to the majority of sorbents in the literature. Alum sludge could be directly reused as the "ready to use media" without any 
Table 4

Determination of the various mass transfer coefficient.

\begin{tabular}{|c|c|c|c|c|c|c|c|c|c|c|}
\hline $\begin{array}{l}\text { Flow rate } \\
(\mathrm{L} / \mathrm{h})\end{array}$ & $\begin{array}{l}\text { Mass } \\
(\mathrm{g})\end{array}$ & $\begin{array}{l}\text { Knudsen } \\
\text { diffusivity } D_{k}\left(\mathrm{~m}^{2} /\right. \\
\mathrm{s})\end{array}$ & $\begin{array}{l}\text { Molecular } \\
\text { diffusivity } D_{m}\left(m^{2} /\right. \\
\text { s) }\end{array}$ & $\begin{array}{l}\text { Effective } \\
\text { diffusivity } D_{e}\left(\mathrm{~m}^{2} /\right. \\
\mathrm{s})\end{array}$ & $\begin{array}{l}\text { Pore diffusion } \\
D_{p}\left(m^{2} / s\right)\end{array}$ & $\operatorname{Re}$ & Sc & Sh & $\begin{array}{l}\text { External mass transfer } \\
\text { coefficient } K_{\text {ext }}(\mathrm{m} / \mathrm{s})\end{array}$ & $\begin{array}{l}\text { Overall mass transfer } \\
\text { coefficient } \mathrm{K}_{\mathrm{a}}\left(\mathrm{s}^{-1}\right)\end{array}$ \\
\hline 5 & 1.0 & $4.98 \times 10^{-5}$ & $1.753 \times 10^{-5}$ & $2.5895 \times 10^{-6}$ & $1.2948 \times 10^{-5}$ & 0.0100 & 0.8490 & 2.2373 & 2.37 & 0.0017 \\
\hline 5 & 0.5 & $4.98 \times 10^{-5}$ & $1.753 \times 10^{-5}$ & $2.5895 \times 10^{-6}$ & $1.2948 \times 10^{-5}$ & 0.0100 & 0.8490 & 2.2373 & 2.37 & 0.0017 \\
\hline 4 & 0.5 & $4.98 \times 10^{-5}$ & $1.753 \times 10^{-5}$ & $2.5895 \times 10^{-6}$ & $1.2948 \times 10^{-5}$ & 0.0080 & 0.8490 & 2.2171 & 2.35 & 0.0017 \\
\hline 3 & 0.5 & $4.98 \times 10^{-5}$ & $1.753 \times 10^{-5}$ & $2.5895 \times 10^{-6}$ & $1.2948 \times 10^{-5}$ & 0.0060 & 0.8490 & 2.1935 & 2.33 & 0.0011 \\
\hline
\end{tabular}

extra treatment. Results demonstrated that alum sludge for $\mathrm{H}_{2} \mathrm{~S}$ control could be an emerging and promising approach for desulfurization. It will pave an avenue for odor control as well as the sustainable sludge management. Indeed, a necessary cost in adsorption technologies is the media replacement, i.e. the replacement of alum sludge in adsorption column in this study. No doubt, the choice of eco-friendly, sustainable, and low-cost alum sludge is in line with the need to develop the "Circular Economy". This is the first time and a small-scale alum sludge- $\mathrm{H}_{2} \mathrm{~S}$ sorption trial and more studies along with large-scale investigations are highly desirable. Moreover, the regeneration of exhausted alum sludge needs further investigation.

\section{Conclusions}

Alum sludge can be used for $\mathrm{H}_{2} \mathrm{~S}$ adsorption (adsorption capacity of $374.2 \mathrm{mg} / \mathrm{g}$ ), this capacity is higher than that of several sorbent reported in literature. Application of Thomas, BDST and YN models suggested that the models can simulate the breakthrough curves, with $\mathrm{R}^{2}$ values ranged from 0.7 to 0.93 . The breakthrough behaviors were regulated by the bed depth and flow rate. The important alum sludge properties for $\mathrm{H}_{2} \mathrm{~S}$ removal are greater specific surface area, microporous volume, alkaline $\mathrm{pH}$, metal species (especially $\mathrm{Ca}, \mathrm{Al}, \mathrm{Fe}$ ) and $\mathrm{O}$-containing groups. The mechanisms study highlighted various resultant sulfur compounds, resulting from a complex reaction mechanism. The overall mass transfer coefficients considering film resistance and pore resistance obtained by numerical modelling allowed to evaluating surface diffusivity of $\mathrm{H}_{2} \mathrm{~S}$ over the interior surface of alum sludge. Since the alum sludge has microporous structure, it can be concluded that Knudsen diffusion was the main diffusion mechanisms. Moreover, the Knudsen, Molecular, Effective and Pore diffusivity were remaining the same under different flow rate and mass of sorbent. It indicated that the adsorption mechanisms were the same regardless of the experimental conditions.

\section{CRediT authorship contribution statement}

Baiming Ren: Methodology, Data curation, Formal analysis, Writing - original draft. Nathalie Lyczko: Software, Investigation, Supervision. Yaqian Zhao: Supervision, Writing - review \& editing. Ange Nzihou: Conceptualization, Methodology, Supervision, Writing - review \& editing.

\section{Acknowledgements}

The first author greatly acknowledges the PhD scholarship received jointly from University College Dublin, Ireland, and China Scholarship Council (CSC). All the technicians in RAPSODEE research centre (CNRS UMR 5302) at IMT Mines Albi, France are also gratefully acknowledged for the technological support.

\section{Appendix A. Supplementary data}

Supplementary data to this article can be found online at https://doi.org/10.1016/j.chemosphere.2020.126010.

\section{References}

Aguilera, P.G., Gutiérrez Ortiz, F.J., 2016. Prediction of fixed-bed breakthrough curves for H2S adsorption from biogas: importance of axial dispersion for design. Chem. Eng. J. 289, 93-98.

Ahmad, T., Ahmad, K., Alam, M., 2016. Sustainable management of water treatment sludge through 3'R' concept. J. Clean. Prod. 124, 1-13.

Ahmed, M.J., Hameed, B.H., 2018. Removal of emerging pharmaceutical contaminants by adsorption in a fixed-bed column: a review. Ecotoxicol. Environ. Saf. 149, 257-266.

Arim, A.L., Neves, K., Quina, M.J., Gando-Ferreira, L.M., 2018. Experimental and mathematical modelling of $\mathrm{Cr}(\mathrm{III})$ sorption in fixed-bed column using modified pine bark. J. Clean. Prod. 183, 272-281.

Bamdad, H., Hawboldt, K., MacQuarrie, S., 2018. A review on common adsorbents for acid gases removal: focus on biochar. Renew. Sustain. Energy Rev. 81, 1705-1720.

Bandosz, T.J., 2002. On the adsorption/oxidation of hydrogen sulfide on activated carbons at ambient temperatures. J. Colloid Interface Sci. 246 (1), 1-20.

Chanaka Udayanga, W.D., Veksha, A., Giannis, A., Lisak, G., Chang, V.W.C., Lim, T.-T., 2018. Fate and distribution of heavy metals during thermal processing of sewage sludge. Fuel 226, 721-744.

Chanaka Udayanga, W.D., Veksha, A., Giannis, A., Liang, Y.N., Lisak, G., Hu, X., Lim, T.T., 2019a. Insights into the speciation of heavy metals during pyrolysis of industrial sludge. Sci. Total Environ. 691, 232-242.

Chanaka Udayanga, W.D., Veksha, A., Giannis, A., Lisak, G., Lim, T.T., 2019b. Effects of sewage sludge organic and inorganic constituents on the properties of pyrolysis products. Energy Convers. Manag. 196, 1410-1419.

de Falco, G., Montagnaro, F., Balsamo, M., Erto, A., Deorsola, F.A., Lisi, L., Cimino, S. 2018. Synergic effect of $\mathrm{Zn}$ and $\mathrm{Cu}$ oxides dispersed on activated carbon during reactive adsorption of $\mathrm{H} 2 \mathrm{~S}$ at room temperature. Microporous Mesoporous Mater. 257, 135-146.

de Franco, M.A.E., de Carvalho, C.B., Bonetto, M.M., de Pelegrini Soares, R., Féris, L.A. 2018. Diclofenac removal from water by adsorption using activated carbon in batch mode and fixed-bed column: isotherms, thermodynamic study and breakthrough curves modeling. J. Clean. Prod. 181, 145-154.

de Oliveira, J.A.P., 2011. Why an air pollution achiever lags on climate policy? The case of local policy implementation in Mie. Japan. Environ. Plan. A 43 (8), 1894-1909.

Dong, Z., Zhao, L., 2018. Covalently bonded ionic liquid onto cellulose for fast adsorption and efficient separation of $\mathrm{Cr}(\mathrm{VI})$ : batch, column and mechanism investigation. Carbohydr. Polym. 189, 190-197.

Fuller, E.N., Schettler, P.D., Giddings, J.C., 1966. New method for prediction of binary gas-phase diffusion coefficients. Ind. Eng. Chem. 58 (5), 18-27.

Gutiérrez Ortiz, F.J., Aguilera, P.G., Ollero, P., 2014. Modeling and simulation of the adsorption of biogas hydrogen sulfide on treated sewage-sludge. Chem. Eng. J. 253, 305-315.

Hervy, M., Pham Minh, D., Gérente, C., Weiss-Hortala, E., Nzihou, A., Villot, A, Le Coq, L., 2018. H2S removal from syngas using wastes pyrolysis chars. Chem. Eng. J. 334, 2179-2189.

Hidalgo, A.M., Murcia, M.D., Gomez, M., Gomez, E., Garcia-Izquierdo, C., Solano, C. 2017. Possible uses for sludge from drinking water treatment plants. J. Environ. Eng. 143 (3), 7.

Hutchins, R., 1973. Newmethods simplifies design of activated carbon systems, Water Bed Depth Service Time analysis. J Chem Eng Lond 81, 133-138.

Klinkenberg, A., 1948. Numerical evaluation of equations describing transient heat and mass transfer in packed solids. Ind. Eng. Chem. 40 (10), 1992-1994.

Kubonova, L., Obalova, L., Vlach, O., Troppova, I., Kalousek, J., 2011. Modelling of NO adsorption in fixed bed on activated carbon. Chem. Process Eng.-Inzynieria Chemiczna I Procesowa 32 (4), 367-377.

Liu, R.B., Zhao, Y.Q., Yang, Y., Awe, O.W., 2018. Diagnosis and evaluation of an earlystage green bio-sorption reactor by life cycle assessment. J. Clean. Prod. 200, $100-109$.

Long, N.Q., Loc, T.X., 2016. Experimental and modeling study on room-temperature removal of hydrogen sulfide using a low-cost extruded Fe203-based adsorbent. 
Adsorption 22 (3), 397-408.

Nam, H., Wang, S., Jeong, H.-R., 2018. TMA and H2S gas removals using metal loaded on rice husk activated carbon for indoor air purification. Fuel 213, 186-194.

Odimegwu, T.C., Zakaria, I., Abood, M.M., Nketsiah, C.B.K., Ahmad, M., 2018. Review on different beneficial ways of applying alum sludge in a sustainable disposa manner. Civ. Eng. J.-Tehran 4 (9), 2230-2241.

Patel, H., 2019. Fixed-bed column adsorption study: a comprehensive review. Appl Water Sci. 9 (3), 45.

Ranz, W.E., Marshall, W.R., 1952. Evaporation from droplets, parts I \& II. Chem. Eng. Prog. 48 (4), 173-180.

Ren, B., Zhao, Y., Lyczko, N., Nzihou, A., 2019. Current status and outlook of odo removal technologies in wastewater treatment plant. Waste Biomass Valorization 10 (6), 1443-1458.

Rout, P.R., Bhunia, P., Dash, R.R., 2017. Evaluation of kinetic and statistical models for predicting breakthrough curves of phosphate removal using dolochar-packed columns. J. Water Process Eng. 17, 168-180.

Sánchez-González, E., Mileo, P.G.M., Sagastuy-Breña, M., Álvarez, J.R., Reynolds, J.E., Villarreal, A., Gutiérrez-Alejandre, A., Ramírez, J., Balmaseda, J., GonzálezZamora, E., Maurin, G., Humphrey, S.M., Ibarra, I.A., 2018. Highly reversible sorption of $\mathrm{H} 2 \mathrm{~S}$ and $\mathrm{CO} 2$ by an environmentally friendly Mg-based MOF. J. Mater. Chem. 6 (35), 16900-16909.

Sharma, S., Verma, A.S., 2013. A theoretical study of H2S adsorption on graphene doped with B, Al and Ga. Phys. B Condens. Matter 427, 12-16.

Shen, C., Zhao, Y.Q., Li, W.X., Yang, Y., Liu, R.B., 2019. Morgan, D. Global profile of heavy metals and semimetals adsorption using drinking water treatment residual. Chem. Eng. J. 372, 1019-1027.

Sigot, L., Ducom, G., Germain, P., 2016. Adsorption of hydrogen sulfide (H2S) on zeolite (Z): retention mechanism. Chem. Eng. J. 287, 47-53.

Singh, A., Pandey, V., Bagai, R., Kumar, M., Christopher, J., Kapur, G.S., 2019. ZnOdecorated MWCNTs as solvent free nano-scrubber for efficient H2S removal Mater. Lett. 234, 172-174.

Siriwardane, I.W., Udangawa, R., de Silva, R.M., Kumarasinghe, A.R., Acres, R.G. Hettiarachchi, A., Amaratunga, G.A.J., de Silva, K.M.N., 2017. Synthesis and characterization of nano magnesium oxide impregnated granular activated carbon composite for H2S removal applications. Mater. Des. 136, 127-136.

Sitthikhankaew, R., Chadwick, D., Assabumrungrat, S., Laosiripojana, N., 2014. Effects of humidity, $\mathrm{O} 2$, and $\mathrm{CO} 2$ on $\mathrm{H} 2 \mathrm{~S}$ adsorption onto upgraded and $\mathrm{KOH}$ impregnated activated carbons. Fuel Process. Technol. 124, 249-257.
Thomas, H.C., 1944. Heterogeneous ion exchange in a flowing system. J. Am. Chem. Soc. 66 (10), 1664-1666.

Wang, J., Wang, L., Fan, H., Wang, H., Hu, Y., Wang, Z., 2017. Highly porous copper oxide sorbent for H2S capture at ambient temperature. Fuel 209, 329-338.

Wang, Y., Ren, B.M., Zhao, Y.Q., English, A., Cannon, M., 2018. A comparison of alum sludge with peat for aqueous glyphosate removal for maximizing their value for practical use. Water Sci. Technol. 450-456.

Wu, H., Zhu, Y., Bian, S., Ko, J.H., Li, S.F.Y., Xu, Q., 2018. H2S adsorption by municipal solid waste incineration (MSWI) fly ash with heavy metals immobilization. Chemosphere 195, 40-47.

Yan, R., Chin, T., Ng, Y., Duan, H., Tee Liang, D., Tay, J.H., 2004. Influence of surface properties on the mechanism of H2S removal by alkaline activated carbons. Environ. Sci. Technol. 38 (1), 316-323.

Yan, R., Liang, D.T., Tsen, L., Tay, J.H., 2002. Kinetics and mechanisms of H2S adsorption by alkaline activated carbon. Environ. Sci. Technol. 36 (20), $4460-4466$.

Yang, Y., Zhao, Y.Q., Liu, R.B., Morgan, D., 2018. Global development of various emerged substrates utilized in constructed wetlands. Bioresour. Technol. 261, $441-452$.

Yoon, Y.H., Nelson, J.H., 1984. Application of gas adsorption kinetics I. A theoretical model for respirator cartridge service life. Am. Ind. Hyg. Assoc. J. 45 (8), 509-516.

Zeng, F, Liao, X.F. Hu, H. Liao, L, 2018, Effect of potassium hydroxide activation in the desulfurization process of activated carbon prepared by sewage sludge and corn straw. J. Air Waste Manag. Assoc. 68 (3), 255-264.

Zhao, X.H., Hu, Y.S., Zhao, Y.Q., Kumar, L., 2018a. Achieving an extraordinary high organic and hydraulic loadings with good performance via an alternative operation strategy in a multi-stage constructed wetland system. Environ. Sci. Pollut. Control Ser. 25 (12), 11841-11853.

Zhao, Y., Liu, R., Awe, O.W., Yang, Y., Shen, C., 2018b. Acceptability of land application of alum-based water treatment residuals - an explicit and comprehensive review. Chem. Eng. J. 353, 717-726.

Zhao, Y., Ren, B., O’Brien, A., O’Toole, S., 2016. Using alum sludge for clay brick: an Irish investigation. Int. J. Environ. Stud. 73 (5), 719-730.

Zheng, M., Hu, H., Zhang, G., Ye, Z., Chen, X., 2017. Combination of adsorptiondiffusion model with CFD for study of desulfurization in fixed bed. J. Environ. Chem. Eng. 5 (4), 4141-4150. 